\title{
A bünügyi adatfeldolgozás hazai fejlődése: út az 1979-es rendőrgyilkosság nyomozásának informatikai támogatásáig
}

\author{
Domestic Development of Criminal Data Processing: \\ The Way to IT Support for the 1979 Police Murder Investigation
}

A bünügyi nyomozás rendeltetése egy múltbeli esemény rekonstruálása, és az erre vonatkozó adatok, bizonyítékok beszerzése. Az ehhez szükséges információkat a nyomozók leggyakrabban a helyszínen, a tanúktól vagy a különféle adatbázisokból szerzik be, de nem elhanyagolható adatforrás a titkos müveletek, az együttmüködők segítsége sem. Egy bizonyos mennyiség felett azonban már a feldolgozó kapacitásának kérdése, hogy mennyire hasznosithatók az adatok. Az 1970-es években ez a bizonyos adatfeldolgozó kapacitás gyakorlatilag az emberi agy teljesítőképességét jelentette, amit legfeljebb úgy lehetett növelni, ha több embert foglalkoztattak egy ügyben. A tudomány adta lehetőségeket felismerve a belügyi szféra elég korán elkezdte az informatikai lehetőségek felhasználását, de az első időszakban ez az állambiztonsági feladatok támogatására szorítkozott.

1979 nyarán Soós Lajos és társai, a fegyverének megszerzése érdekében, brutális kegyetlenséggel meggyilkolták a föváros határában lévő Steinmetz-szobornál szolgálatot teljesitő Gyulai Károly rendőr fötörzsőrmestert. Az egész országot megrázó és megmozgató bünügy felderítése során olyan mennyiségü adat keletkezett, amelynek feldolgozása, kezelése meghaladta az addigi gyakorlatot.

A technika fejlődésének lehetőségei, az állambiztonsági területen már megkezdett számítástechnikai fejlesztések, és a bünügy felderítésével szemben támasztott elvárások utat nyitottak a bünügyi elemzés informatikai eszközökkel történő támogatásához, ami a későbbi továbblépések és szabályozások alapjait is jelentette. A tanulmány a bünügyi nyilvántartás és elemzés hazai történetének rövid ismertetése mellett ezeket a körülményeket, alkalmazásokat és eredményeket mutatja be, az említett emberölés nyomozásának tükrében. 
Kulcsszavak: bünügyi elemzés, informatikai támogatás, Soós Lajos, Gyulai Károly, rendörgyilkosság

The purpose of a criminal investigation is to reconstruct a past event and to obtain the relevant data and evidence. The information needed for this is most often obtained by investigators on the spot, from witnesses, or various databases, but the help of covert operations and confidential informants are not negligible sources of data either. Above a certain amount, however, it is already a question of processing capacity, how well the data can be utilised. In the 1970s, this particular processing capacity meant practically the performance of the human brain, which could only be increased by employing more people in a case. Recognising the opportunities provided by science, the Ministry of the Interior started to take advantage of IT opportunities quite early, but in the first period, it focused on supporting intelligence tasks.

In the summer of 1979, Lajos Soós and his accomplices brutally murdered Police Chief Staff Sergeant Károly Gyulai, who was serving at the Steinmetz statue in the suburban of the capital, to obtain his weapon. During the detection of the crime that shook and moved the whole country, such a large amount of data was generated, the processing and handling of which exceeded the previous practice.

The possibilities of technological development, the computer developments already started at the intelligence service, and the expectations placed on the detection of crime also opened the way to support criminal analysis with IT tools, which also formed the basis for later developments and regulations.

In addition to a brief description of the domestic history of criminal records and analysis, the study presents these circumstances, applications and results in light of the investigation into the said murder.

Keywords: criminal analysis, IT support, Lajos Soós, Károly Gyulai, police murder

\section{Bevezetés}

Az első, kartonokkal dolgozó nyilvántartó osztályoktól elindulva hosszú utat tett meg az információ nyilvántartásának, feldolgozásának és továbbításának fejlődése az információs fúziós központok létrejöttéig.

A mai világban szinte elképzelhetetlen a 21. századi informatikai eszközök támogatása nélküli adatfeldolgozás és bünügyi elemzés. Az első számítógépek megjelenése után rövid időn belül felmerült ezek belügyi hasznosításának a kérdése is. A mikroelektronikai alkatrészek megjelenése, a szobaméretű berendezéseket felváltó asztali számítógépek, majd az informatika és a telekommunikáció folyamatos fejlődése jelentős segítség a búnüldözésben, de - a búnelkövetők által használva - egyben újabb kihívásokat is jelent.

Az adatfeldolgozás és a bünelemzés hazai történetének áttekintése kevés helyen található meg egy tanulmányban. A legtöbb munka az állambiztonsági területen lezajlott fejlesztéseket, változásokat mutatja be, de a bünügyi relevanciájú események, 
történések ismertetése hiányos. Különösen nehéz konkrét ügyeket, kiemelt bünügyeket összekapcsolni a bűnelemzéssel. Évekkel ezelőtt, az akkori szolgálati helyemen volt szerencsém megismerni az 1979-ben Gyulai Károly sérelmére elkövetett rendőrgyilkosság selejtezésre váró nyomozati iratainak és értékelő jelentéseinek egy részét. Az iratok részben a nyomozás eredményeit foglalták össze, részben pedig a felderítés érdekében javasolt számítástechnikai adatfeldolgozást mutatták be.

A jelentések készítői és jóváhagyói között a rendészettudomány olyan jeles képviselői szerepeltek, mint a Belügyminisztérium Országos Rendőr-főkapitányság (BM ORFK) Vizsgálati Osztályát akkor vezető dr. Katona Géza, a BM ORFK Bűnügyi Technikai Osztály vezetője, dr. Kertész Imre, illetve dr. Kacziba Antal, aki a rendszerváltás után altábornagyként az ORFK bünügyi főigazgatója, majd a BM rendvédelmi helyettes államtitkára volt.

A tanulmányozott, iktatószám nélküli iratok közül kiemelendő az 1979. december 14-én készült, három részből álló, összesen 89 oldalas értékelő-elemző jelentés, illetve a nyomozás során keletkezett adatok számítástechnikai feldolgozására irányuló, 1979. augusztus 7-én kelt 10 oldalas javaslat, és az annak megvalósításáról szóló, 1979. december 19-én készült 25 oldalas jelentés és mellékletei.

A tanulmányomban igyekeztem az emberöléssel kapcsolatban máshol már megjelent adatokat kiegészíteni és pontosítani. A minősítés megszűnésének ${ }^{2}$ ellenére kerültem az operatív felderítés ${ }^{3}$ során alkalmazott erők, eszközök vagy módszerek bemutatását, vagy olyan személyek nevesítését, akik korábban nem szerepeltek más, nyilvánosan is hozzáférhető forrásokban.

A dokumentumokból érdekes és izgalmas kép alakult ki az 1970-es évek második felének bűnügyi helyzetéről, illetve a kiemelt közérdeklődésre számot tartó ügyekben bevezetett intézkedésekről, amit a bünügyi nyilvántartás, adatfeldolgozás és bünelemzés kialakulásának, fejlődésének bemutatásával egészítettem ki. ${ }^{4}$

\section{A nyilvántartás és az adatfeldolgozás kezdete}

Az értékelő-elemző munka elengedhetetlen forrásai a nyilvántartásokban kezelt adatok, ezen belül is az olyan bűnügyi információk, mint például a korábban már elítélt személyek adatai, az azonosításukat elősegítő jellemzők (személyleírások, ismertetőjegyek, fényképek, daktiloszkópiai nyomok) vagy a jellegzetes elkövetési módszerek.

A rendőrségen, az addigi nyomozói feljegyzéseket felváltó bűnügyi nyilvántartás alapjait 1885-ben, dr. Török János ${ }^{5}$ főkapitánysága alatt teremtették meg. Az ekkor felállított detektívtestület kezelésében lévő adatbázis első lépésként négy részből (rovott

A 1539/79. bü. számon folytatott nyomozással összefüggésben keletkezett jelentések korábbi minősítése az államtitokról és szolgálati titokról szóló 1995. évi LXV. tv. 28. § (2) bekezdése alapján megszűnt.

A mai leplezett eszközök alkalmazásának és a titkos információgyűjtésnek megfelelő konspirált tevékenység korabeli terminológiája.

Az érintett szervezeteket és vezetőiket az 1. sz. mellékletben összesítettem és mutatom be.

Dr. Török János (1843-1892), jogász és politikus, 1885-1892 között a Budapest-fővárosi rendőrség főkapitánya. Irányítása alatt a kétes megítélésű, bűnözői kapcsolatokkal terhelt Theisz Elek főkapitánysága után a rendőrség egy fejlődő korszakát élte. Beosztásában az 1892. szeptember 4-én bekövetkezett halálig maradt. 
múltúak és körözöttek, a lopott tárgyak és talált értékek, a feltételesen szabadságra bocsátottak, a rendöri közlönyök) álló struktúrája nem sokkal később a fényképes nyilvántartással és a tömeglakásokról, búvóhelyekről és játékbarlangokról vezetett adatokkal is kibővült. ${ }^{6}$ Már ekkor egyértelmü volt, hogy az adatok mennyisége szükségessé teszi azok rendszerezését, kezelhetővé és kereshetővé tételét.

A nyilvántartás a későbbi években, évtizedekben szinte azonos rendszerrel működött. A kartonokra és nyilvántartólapokra feljegyzett információkat, fényképeket tartalmazó adathalmazokat manuálisan és egymástól elszigetelten kezelték.

A nyilvántartás módszere ugyan nem sokban változott, de az azt végrehajtó szervezet és a szabályozottság igen. Az egyik ilyen legfontosabb változás az 1909-ben Gábor Béla7 vezetésével megalakult Országos Bünügyi Nyilvántartó Hivatal (OBNYH) ${ }^{8}$ volt, amelynek feladatát 1914-ben így írta le a büntetőjogról szóló tankönyvében dr. Finkey Ferenc: „[A] kir. ügyészség, illetőleg a járásbíróság (vagy az első fokú közigazgatási hatóság) büntetőlapot állít ki minden jogerős ítéletről, melyben a bíróság bűntettet, szabadságvesztéssel büntethető vétséget, csavargás, koldulás kihágását vagy egy hónapot meghaladó elzárással büntetett más kihágást állapított meg. A büntetőlapok az egész országból az országos bünügyi nyilvántartó hivatalhoz küldendők be, mely hivatal az igazságügyi és belügyi ministerek felügyelete s a budapesti államrendőrség főkapitányának vezetése alatt áll. E nyilván tartó hivatal vezeti az ujjlenyomatok és fényképek nyilvántartását. E hivataltól kell kérni hivatalos értesítést a bünügyekben eljáró hatóságoknak. Magánosok az országos bűnügyi nyilvántartásból értesítést nem kaphatnak." ${ }^{\prime 9}$

A politikai rendészet területén az 1920-as évek közepén világossá vált, hogy szükség van önálló, a szakterületre jellemző adatokra épülő nyilvántartásra is. Ennek megalkotására dr. Hetényi Imre ${ }^{10}$ adott utasítást, és annak kialakítását Hein Péter, az Állambiztonsági Rendészet későbbi vezetője irányította.

Az egységes, kartotékos nyilvántartáson túl 1931-ben került először kiadásra az évente megjelenő Államvédelmi Zsebkönyv (ÁZS) is, amelyben a személyekhez tartozó és az államvédelem szempontjából releváns információkat betűkódokkal jelölték (például: „A.” - magyar állami eszme ellen izgató, a magyar nemzetet következetesen becsmérlö egyén; „K." - kommunista tevékenységet kifejtő, igy gyanú alatt álló egyén). A kezdeti 9 kódból később 16 kategória lett, de a legtöbb csak figyelemfelhívásra szolgált, érdemi intézkedést az alapján nem lehetett foganatosítani. A más

Perényi Roland: A bün nyomában. A budapesti bünözés társadalomtörténete 1896-1914. Budapest, L’Harmattan, 2012. 66-67.

7 Gábor (Hollefreund) Béla (1873-1939), rendőr tisztviselő, a hazai daktiloszkópia megteremtője, 1909-1917 között a Bűnügyi Nyilvántartó Hivatal vezetője, utána a bűnügyi osztály helyettes vezetője, majd 1919-től a Budapestvidéki Kerületi Főkapitányság főkapitánya volt az 1920-ban kért nyugdíjazásáig.

1908. évi 24.300 IM. sz. rendelet alapján, 1909. január 1-jei hatállyal létrehozott hivatal.

Finkey Ferencz: A magyar büntetőjog tankönyve. Budapest, Grill Károly, 1914. 161.

Dr. Hetényi Imre (1871-1946), orvos, jogász. Bűnügyi tudósítóként kezdte pályáját. 1922-től a Budapesti Rendőr-főkapitányság Útlevél és idegenellenőrző osztályának, majd 1932-től a Politikai Nyomozó Osztály, 1933-tól az Államrendészeti Osztály vezetője lett, 1922-től főkapitány-helyettesi címet viselt. 1932-től az újjászervezett politikai osztályt vezette az 1938-as nyugdíjazásáig. Rendőri munkája mellett publikált is, 1941-ben Amikor a rend őre voltam címmel írta meg önéletrajzát. 
néven „Fekete könyvek” néven is nevezett kiadványok bizalmasak voltak, a szolgálati közegek kizárólag szolgálati idejükre kapták meg, és abba tilos volt bármit bejegyezni. ${ }^{11}$

A hírszerzés és a kémelhárítás világában is kiemelt szerepe volt a nyilvántartásnak. A katonai szakterületen ${ }^{12}$ belül a nyilvántartó alosztály („NYIL”) további arcvonalakra (például szovjet, balkáni, román, bolgár, angol) osztódott. Itt az egyes országok katonai, politikai és gazdasági helyzetét kísérték figyelemmel és tartották nyilván. Az alosztályhoz érkezett be minden felderítési adat a hírszerzőktől, katonai attaséktól vagy más forrásokból (rádióadások figyelése, újságok elemzése stb.). Az alosztálynál napi „Hírnaplót” vezettek az elmúlt 24 órában beérkezett összes hírről, a forrás és a megbízhatósági fok feltüntetésével. ${ }^{13}$

A Il. világháború során az OBNYH - akkor már 1,5 millió adatlapot, 500 ezer daktiloszkópiai lapot és mintegy 60 ezer fényképet tartalmazó - adatbázisát külföldre, a csehországi Theresienstadtba (ma Terezin) szállították, ahol az megsemmisült. ${ }^{14}$ Az adatállomány nagy részét helyreállították, majd 1950-ben a hivatalt megszüntették, és a bűnügyi nyilvántartás a Belügyminisztérium kezelésébe került. ${ }^{15}$

Az új bűnügyi nyilvántartást előbb az 1954-es „Nyilvántartási Utasítás”, ${ }^{16}$ majd az azt 1958-ban hatályon kívül helyező „Bűnügyi Nyilvántartási Utasítás”17 szabályozta, amelynek végrehajtására az ORFK Bünügyi Nyilvántartó Osztályát jelölték ki. Utóbbi utasítás a bűnügyi nyilvántartás jelentőségét így határozta meg: „A bűnügyi nyilvántartásnak elő kell segítenie a bűnözés és a bűnözők tevékenységének értékelését, képet kell adnia azok elhelyezkedéséről, az ellenük szervezett hálózati munka alakulásáról, pontos előéleti és terhelő adatokat kell szolgáltatnia a prioráló szervek részére, és a különleges nyilvántartások alapján aktív segítséget kell nyújtania az ismeretlen tettesek felderítéséhez, a szokásos bűnözők felméréséhez, ellenőrzés alatt tartásához."18

A hazai viszonyok között az első gépi adatfeldolgozás kialakítása 1958-ban kezdődött meg, amely a rögzített adatok manuális kezelése helyett az úgynevezett Hollerith-rendszerü, ${ }^{19}$ lyukkártyás elven működő gépi feldolgozást tűzte ki célul. Az egyik első ilyen számítógépet - a BM XII. osztályként 1957 májusában

$11 \quad$ Kovács Tamás: Megfigyelés, internálás, deportálás az internálás és a toloncolás kérdésköre a két világháború között, különös tekintettel a II. világháború korára. Doktori értekezés. Pécs, PTE BTK Interdiszciplináris Doktori Iskola, 2013. 170.

12 1920-tól a HM VI-2. osztály, majd 1938-tól 2. vkf. osztály által végzett tevékenység.

13 Boda József - Regényi Kund: A hírszerző és biztonsági szolgálatok fejlődése a második világháború végéig. In Boda József - Regényi Kund (szerk.): A hírszerzés története az ókortól napjainkig. Budapest, Dialóg Campus, 2019. 118.

14 Ismeretlen szerző: Kétszázezer ujjlenyomat van már a rendőrség birtokában. Demokrácia, (1946), 23. 7.

15 5372-1/1950. (VIII. 11.) BM rendelet „Az országos bűnügyi nyilvántartással kapcsolatos tennivalók ellátása és a körözések közzététele” tárgyában; Rudas György: A bűnügyi nyilvántartás fejlődése. Rendőrségi Szemle, 7. (1959), 1. 30.

16 Az 1954. január 08-án kiadott, 02. számú belügyminiszter-helyettesi parancs, és annak 239/1953. számú melléklete.

17 Az ORFK vezetőjének 1958. május 5-én kelt 5. számú utasítása, és annak melléklete (ÁBTL-4.2-50-6/5/1958).

18 ÁBTL-4.2-50-6/5/1958. 1.

19 A feltalálójáról, Herman Hollerith (1859-1929) német származású amerikai statisztikusról elnevezett adatfeldolgozó rendszer, amelynek alapját a vékony kartonon lévő lyukak elhelyezkedése jelentette. 
létrehozott ${ }^{20}$ - Országos Rejtjel Központ alkalmazta a rejtjelfejtési munka támogatására, illetve a rejtjelező kódkönyvek gépi úton történő készítéséhez. ${ }^{21}$

1962 augusztusában a BM-et szovjet mintára átszervezték, és kialakult az a szervezeti struktúra, amely a rendszerváltásig szinte változatlan maradt. A szakterületek ismét főcsoportfőnökségek lettek, amelyek közül a II. Főcsoportfőnökség látta el az Országos Rendőr-főkapitányság feladatát, míg a III. Főcsoportfőnökség lett a központi állambiztonsági szerv. A területi (megyei) állambiztonsági szervek osztály jogállással továbbra is a megyei (budapesti) rendőr-főkapitányságok szervezetében maradtak, de szakmai irányításukat ezután is a III. Főcsoportfőnökség végezte. Ebből a kettős irányítási rendszerből, illetve a korszakot jellemző politikai elvárásokból eredően a búnügyi és az állambiztonsági munka összemosódott, és az állambiztonsági érdekek gyakran felülírták a bűnügyi feladatokat.

A BM átszervezésével a Bűnügyi Nyilvántartó Osztály a II/I-5. számozását kapta, és vezetőjének Ollé Ernő rendőr alezredest nevezték ki. A feladatrendszer annyiban változott, hogy a Körözési Alosztály a II/I-2. (Bünügyi) Osztályhoz került. A főkapitány közvetlen irányítása alatt II/1. számozással létrejött egy önálló statisztikai értékelő osztály is, amelyet dr. Lázár Bertalan rendőr őrnagy vezetett. ${ }^{22}$ Idővel ez utóbbi beolvadt a II/1-5. osztályba, amely ezt követően Bűnügyi Nyilvántartó és Statisztikai Osztályként müködött tovább.

Az 1965-ben elrendelt átfogó selejtezés keretében a nyilvántartás adatállományát csökkentették, így többek között törölték az 1945 előtt elítéltek, vagy az időközben megváltozott tárgyi súlyú búncselekmények - mint az államosítás alá eső ház bejelentésének elmulasztása, vagy a munkafegyelem-sértéssel elkövetett tervbüntett - miatt nyilvántartásba vett személyek adatait. A munka volumenét tükrözi, hogy a végrehajtására közel két év állt rendelkezésre. ${ }^{23}$

Az állambiztonsági vonalon - az értékelő-elemző feladatokat addig ellátó II/3. osztály utódaként - ezzel az átszervezéssel alakult meg a III/4. számozású, ${ }^{24}$ közvetlen főcsoportfőnöki irányítás alá tartozó, Elemző értékelő, nemzetközi kapcsolatok és tájékoztató osztály, amelynek vezetője Márkus Sándor rendőr alezredes lett. ${ }^{25}$ Az osztály ebben a formában ugyan 1965. június 1-jei hatállyal megszűnt, de az értékelő-elemző terület a főcsoportfőnöki titkárságon belül tovább múködött. ${ }^{26}$

Az 1967-es esztendő mind az adatfeldolgozásban, mind az értékelő-elemző munka területén jelentős eredményeket és változásokat hozott. Ekkor adták ki a bűnügyi felderítéssel kapcsolatos adatszolgáltatást és adatfeldolgozást, a kezelt adatok körét,

Müller Rolf: Az operatív technikai osztály, 1956-1962. Betekintő, (2011), 3. 6.

Cseh Gergő Bendegúz -Tóth Eszter: A magyar állambiztonsági szervek központi nyilvántartási rendszere és annak számítógépesitése (1962-1990). In A Nemzeti Emlékezet Bizottsága és az Állambiztonsági Szolgálatok Történeti Levéltára közös munkacsoportjának jelentése az 1990 elötti állambiztonsági szervek mágnesszalagokon megőrzött adatállományának vizsgálatáról. Nemzeti Emlékezet Bizottsága, 2017. 31. BM Titkárság 10-1513/1962. számú, 1962. 08. 29-én kelt körlevele. (ÁBTL-4.2.-10-1513/1962.)

0014/1965. (IX. 17.) BM utasítás a BM Bűnügyi Nyilvántartó Osztály nyilvántartási anyagának selejtezéséről. (ÁBTL- 4.2.-10- 22/14/1965.)

24 A III/4. számozás 1971-ig az elemző-értékelő területet jelölte, majd 1972-től az operatív-technikai ellenőrző szerv („X” ellenőrzés) jelölése lett.

25 BM Titkárság 10-1513/1962. számú, 1962.08.29-én kelt körlevele. (ÁBTL-4.2.-10-1513/1962.)

26 0021/1965.(VI. 1.) és a 0023/1965. (VI. 1.) belügyminiszteri parancsok. (ÁBTL-4.2.-10-21/21/1965. és ÁBTL4.2.-10-21/23/1965.) 
illetve az abból történő tájékoztatás rendjét szabályozó belügyminiszter-helyettesi parancs mellékleteként a Bünügyi Nyilvántartás Szabályzatát. ${ }^{27}$ Az adatok feldolgozása és kezelése a BM ORFK Bünügyi Nyilvántartó és Statisztikai Osztályán zajlott, amely magában foglalta mind a nyílt forrásból származó (például korábban elítéltek, vagy a személy- és tárgykörözések), mind az operatív rendőri tevékenység (például környezettanulmány, figyelések) során keletkezett adatokat.

Szintén 1967-ben alakult ismét osztállyá az állambiztonsági terület III/4. számozású elemző-értékelő egysége is, de a korábbiaktól eltérően, immár profiltisztán. A Hajdú Pál rendőr ezredes vezette osztállyal szemben támasztott elvárások teljesítése már tényleges értékelő-elemző munkát igényelt, amelynek során vizsgálni kellett:

- az ellenséggel szemben foganatosított állambiztonsági intézkedéseket és azok hatását;

- a külső ellenség és a belső reakció helyzetét, szándékait, tevékenységét, valamint

- az ellenséges aknamunka felderítésében elért eredményeket. ${ }^{28}$

Az elemző feladat később tovább bővült, és ki kellett térnie:

- a külső és belső ellenség jellemzésére, tevékenységére, taktikájára, módszereire és eszközeire vagy az állambiztonsági munka módszereinek és eszközeinek alkalmazására, illetve

- az általánosítható ismeretekre, tapasztalatokra, értékelésekre is. ${ }^{29}$

A feladatszabás mellett egyben a hatékony munka előfeltételeként határozták meg a gépi adatfeldolgozás megszervezését, amelynek támogatására létrejött a BM III/V-4. Osztály ${ }^{30}$ gépi adatfeldolgozó alosztálya. 1968-ban megszületett a belügyi szerveknek többéves időszakra feladatokat adó „TITÁN” fejlesztési terv, amelynek főbb célkitüzései az alábbiak voltak:

- korszerű számítástechnikai eszközökkel segíteni a belügyi szervek munkáját, amelyek lehetővé teszik az információk közötti összefüggések szélesebb körü feltárását;

- a különböző belügyi nyilvántartások manuális munkafolyamatainak számítógépesítésével egységesebbé, szervezettebbé, gyorsabbá tenni az adatszolgáltatást, az információk feldolgozását;

- elemzésre, értékelésre alkalmas, összesített adatokat szolgáltatni a vezetés részére, amelyek elősegítik a viszonylag optimális döntéshozatalt. ${ }^{31}$

$27 \quad$ A 01/1967. számú belügyminiszter-helyettesi parancs mellékleteként kiadott, „A bűnügyi nyilvántartás szabályzata, I-II.". (ÁBTL-4.2.-10-1190/1967. és ÁBTL-4.2.-10-1190-1/1967.)

28 A 0020/1967. (VII. 29.) belügyminiszteri parancs, és annak végrehajtási utasításai. (ÁBTL-4.2.-10-21/20/1967.)

29 A 0020/1967. (VII. 29.) belügyminiszteri parancs 1969. 11. 30-án kelt végrehajtási utasításának 3. pontja. (ÁBTL-4.2.-10-21/20/1967/14.)

$30 \quad 1967$ júliusától érvényes számozás szerint Rejtjelkészítő, rejtjelfejtő és gépi adatfeldolgozó osztály.

31 34/1977. számú belügyminiszteri parancs A számítástechnika belügyi alkalmazásának, a számítógépes információrendszerek fejlesztésének egységes szabályozásáról „A számítástechnika belügyi alkalmazásának fejlesztési irányelvei" címú melléklete, 12. (ÁBTL- 4.2-10-22/34/1977/11.) 
A terv végrehajtása érdekében 1971-ben a BM-t jelentősen átszervezték. ${ }^{32} \mathrm{Az}$ adatfeldolgozó és az elemző-értékelő szakterületet különválasztották, ami új, közvetlen államtitkári irányítás alatt álló szervezeti egységeket eredményezett. Az új szervezeti felépítést az 1. ábra mutatja be.

Az egységes, központosított adatkezelés és -feldolgozás érdekében létrejött az állambiztonsági, a bünügyi, valamint a lakcím- és közlekedési nyilvántartásokat kezelő BM Nyilvántartó Központ (BM NyK), amelynek vezetője dr. Selmeczi György rendőr ezredes lett.

Az elemző-értékelő területen a későbbi belügyminiszter, dr. Kamara János rendőr ezredes vezetésével alakult meg a BM Információ-feldolgozó és Felügyeleti Csoportfőnökség, amely többek között integrálta a korábbi BM III/4. (Értékelő-Elemző) Osztályt, a BM III/V-4. Osztály gépi-adatfeldolgozó alosztályát, valamint a rendőrségről a BM II/I-5. Osztály értékelő- és statisztikai alosztályát. A csoportfőnökség egyik osztálya lett az Értékelő-Elemző Osztály, amelynek három alosztálya elkülönülten értékelte az állambiztonsági, a rendőri-bünügyi és a rendészeti-igazgatási munkát.

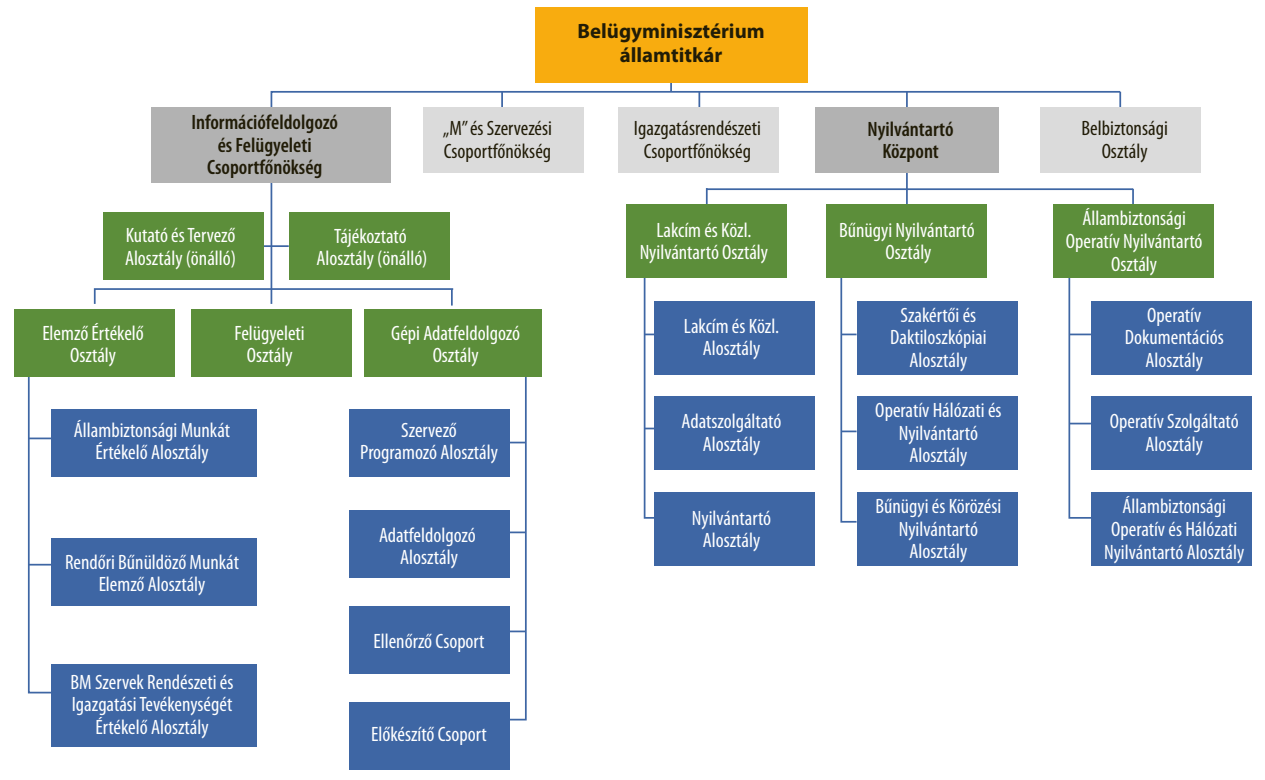

1. ábra

Az államtitkár közvetlen irányitása alatt álló belügyi szervek 1971-1974 között

Forrás: a szerző szerkesztése https://neb.hu/asset/phpadHQ5g.pdf alapján 
1974 végén a Felügyeleti Osztály a miniszter közvetlen alárendeltségébe, míg az önálló Kutató és Tervező Alosztály a BM Tudományszervezési Osztály keretébe került, és a szervezet neve Információfeldolgozó Csoportfőnökségre módosult. ${ }^{33}$

1974-től fokozatosan vezették be az egységes Gépi Prioráló Rendszert (EGPR), amely a kérdező jogosultsági szintjéhez igazodva akár 14 - bünügyi, igazgatásrendészeti és állambiztonsági - nyilvántartásból tudott egyéni vagy csoportos kérdőjegy alapján adatot szolgáltatni. A központi adatfeldolgozóhoz a kérdőjegyek a titkos ügykezelés szabályainak maradéktalan betartása mellett, részben speciális tasakokban futárok útján, részben lyukszalagos kódolással jutottak el. $A$ válaszokhoz a bűntettesi („A"), a modus operandi („, $\left.\mathrm{B}^{\prime \prime}\right)$, vagy a veszélyes bünözői ${ }^{34}$ („C') adattárak mellett olyan szenzitív nyilvántartásokat is ellenőriztek, mint például az állambiztonsági operatív nyilvántartás („, $\left.G^{\prime \prime}\right)$ vagy a központi kémelhárítási adattár $\left({ }_{\text {, }} \mathrm{K}^{\prime \prime}\right) \cdot{ }^{35} \mathrm{~A}$ válasz a konkrét eljárásokról információkat nem tartalmazott, csak a kérdezett személy előfordulását jelezte az adott adatbázisban, és megjelölte az eljáró szervet.

Az átmenetileg különálló nyilvántartó és információfeldolgozó területeket 1977-ben ismét összevonták, ${ }^{36}$ és Baranyai György rendőr vezérőrnagy vezetésével megalakult a BM Adatfeldolgozó Csoportfőnökség (BM AFCS), amely - a Felügyeleti Osztály kivételével - gyakorlatilag a korábbi osztályokkal működött.

Ez a centralizált szervezet a rendszerváltásig fennmaradt, sőt idővel a tájékoztatási feladatkör is visszakerült hozzá, és 1984-től BM Adatfeldolgozó és Tájékoztatási Csoportfőnökség lett.

Az államtitkár közvetlen irányítása alá tartozó új szervezeten belül egyszerre jelentkezett feladatként a politikai és a szakmai vezetés tájékoztatása, az állampolgárok és a járművek nyilvántartása, a bűnügyi nyilvántartásban szereplő adatok kezelése és az azokból történő adatszolgáltatás, a bünügyi és az állambiztonsági szervek - nyílt és operativ - eljárásai során keletkezett információk feldolgozása és értékelése, valamint a velük titkosan együttmúködő személyek adatainak nyilvántartása.

Az informatikai rendszerek belügyi hasznosítását célul kitűző „TITÁN” terv részletes értékelésére, és az új feladatok, irányok kijelölésére 1977 végén került sor. Eszerint az eredeti célkitűzések részben teljesültek és eredményesek voltak, de több ponton hiányosságot állapított meg. Így például „a számítógépes adatfeldolgozó rendszerek szervezése elsősorban a minisztérium információrendszerének meglevő adottságaira, manuális adatfeldolgozó és nyilvántartó rendszereire támaszkodott, a számítástechnika lehetőségei csak részben kerülhettek hasznosításra”, vagy „az adatgyűjtés során az információknak a számítógéphez történő áramlása lassú, bonyolult adminisztrációt igényel". 37

33 018/1974. (XI. 18.) belügyminiszteri parancs. (ÁBTL-4.2-10-21/18/1974.)

34 Veszélyes bűnöző: először a 05/1963. (VI. 17.) belügyminiszter-helyettesi parancs 2. számú mellékletében értelmezett, és a rendszerváltásig érvényes gyűjtőfogalom, akiket a rendőrség rendszeresen és fokozottan ellenőrzött.

35 02/1974. (IV. 8.) BM Információfeldolgozó és Felügyeleti Csoportfőnöki Utasítás. (ÁBTL- 4.2-65-6-2/1974.) 9/1977. (V. 30.) belügyminiszteri parancs. (ÁBTL- 4.2-10- 22/9/1977.)

34/1977. (XII. 1.) BM parancs a számítástechnika belügyi alkalmazásának, a számítógépes információrendszerek fejlesztésének egységes szabályozásáról. (ÁBTL- 4.2-10-22/34/1977.) 
Ezek a kritikai észrevételek már előrevetítették az információáramlás, illetve az adatfeldolgozás számítástechnikai támogatásának fejlesztési igényét, amelyre az aktuális búnügyi események kihívásai is rávilágítottak.

\section{Az 1970-es évek búnügyi helyzete}

Az 1956-os forradalmat követő megtorlás után, az 1960-as évek elejétől egy konszolidáltabb időszak köszöntött be. Ezekben az években a világban hidegháború dúlt, miközben a Balatonnál a nyugatról és keletről érkező - és az ekkor épülő berlini fallal elválasztott - németek találkoztak egymással titokban. A gazdasági élet nyitottabbá vált, majd az 1970-es évektől megjelent a magánszektor, és fejlődésnek indult a turizmus. Az ideérkezők egyrészt új elkövetési módszereket hoztak magukkal, másrészt fizetőképes keresletet jelentettek mind a vendéglátásban, mind pedig a prostitúció és az illegális műkincs-kereskedelem területén. A regisztrált bűncselekmények számának 1965-1980 közötti alakulását a 2. ábra mutatja be. Ebben az időszakban az lényegesen nem változott, két év $(1969,1974)$ kivételével 120 és 130 ezer között volt évente.

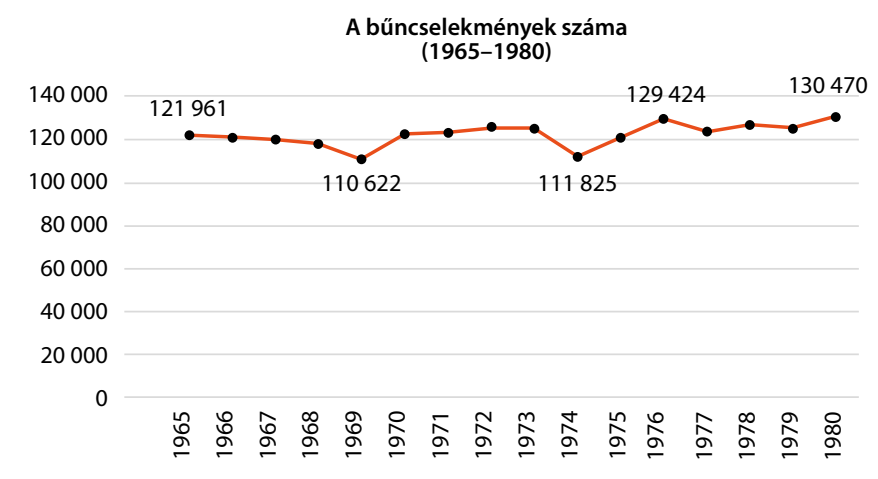

2. ábra

Az ismertté vált büncselekmények számának alakulása 1965-1980 között

Forrás: a szerző szerkesztése KSH-adatok www.ksh.hu/docs/hun/xstadat/xstadat_hosszu/h_zjj001.html alapján

1975-ről az ismertté vált bűncselekmények közül 1980-ra a betöréses lopások száma 127\%-ra, a rablások száma 180\%-ra emelkedett, míg az erőszakos közösülés és az emberölések (vagy azok kísérletének) száma közel 20\%-os csökkenést mutatott. ${ }^{38}$

A lakossághoz elsősorban azok a gyilkosságok, a közterületeken elkövetett erőszakos cselekmények (galeribűnözés) vagy a sorozatban elkövetett betöréses lopások, csalások hírei jutottak el, amelyek megítélése politikai világnézettől függetlenül is egyértelmű volt. A közvélemény irányított tájékoztatása részben a televízió 
Kékfény című műsorán keresztül, részben pedig a bírósági tárgyalásokról szóló újságírói tudósításokban merült ki. Ezeknél a vádlottak személyiségi jogai háttérbe szorultak, és már az eljárás kezdetétől a teljes nevükön, sokszor életkoruk és foglalkozásuk megjelölésével szerepeltek a korabeli médiában.

A közbiztonság helyzetének esetleges romlását vagy a szervezett bünözés megjelenését a párt elvárásainak megfelelően következetesen cáfolták az akkori tudományos élet képviselői is. Dr. Gödöny József, az Országos Kriminológiai Intézet intézetalapító igazgatója 1975-ben így fogalmazott: „A szocialista országokban létező bűnözés struktúrájának megítélésénél alapvető jelentőségű, hogy egyrészt nincs szervezett bűnözés, másrészt hiányzik a kábítószer-kereskedelem és fogyasztás, úgyszintén a fehérgalléros bűnözés is. E bünözési formák hiánya azt jelenti, hogy minőségi különbség van a szocialista és a tőkésországok kriminalitása között."39

Az 1970-es évek második felében azonban több olyan kiemelt bűncselekmény is történt, amely a párt által a közbiztonságról sugárzott ideális képet árnyaltabbá tette:

1975. július 1-jén a Budapest VIII. kerület, Bródy Sándor utca 6. szám előtt két, intézkedés alá vont férfi egy vascsővel életveszélyesen megsebesítette a velük szemben intézkedő Turóczi Ferenc rendőr tizedest, majd eltulajdonították lőfegyverét. Az elkövetőket nem sokkal később azonosították és elfogták.

1976. szeptember 17-én a büntetett előéletű Miskei Imre a fővárosi Halászbástyán elcsalt, majd egy félreeső helyen megölt egy iskolába tartó 8 éves kislányt. Az elkövetőt 10 nappal később a budakeszi erdőben fogták el, majd a bíróság halálra ítélte. ${ }^{40} \mathrm{Az}$ ítéletet - a büncselekmény után alig 6 hónappal - 1977. március 29-én végre is hajtották. ${ }^{41}$

1977. március 4-én ismeretlen tettes a Budapest VIII. kerület, Hungária körút 10/a. szám alatti OTP-fiókban két alkalmazottat lelőtt, majd 113.600 Ft-tal elmenekült. A büncselekményhez a tettes egy 7,62 kaliberü, 48-as mintájú TT pisztolyt használt. A tanúvallomásokkal az elkövetés idejét sikerült 5 percre, 14:12 és 14:17 közöttire szúkíteni. A helyszíni szemlén rögzített, azonosításra alkalmas ujjnyomok közül $8 \mathrm{db}$ ismeretlen személytől származott, továbbá idegen hajszálat is találtak. ${ }^{42} \mathrm{~A}$ biztató adatok és a széles körű nyomozás ellenére a kettős gyilkosság elkövetőjét nem sikerült felderíteni, az a mai napig ismeretlen.

A fenti kiemelt ügyeken túl az évtized utolsó évére is jutott rendkívüli a bünügyi eseményekből:

A fővárosban a XVI. kerületi Veress Péter utcában lévő postahivatal mellett az év elején, lopott gépkocsival két alkalommal is kirabolták a közeli közért bevételét szállító alkalmazottakat. Pár hónappal később, szeptember 14-én este feltehetően ugyanezek a tettesek a III. kerületi Törzs utcában is hasonló módszerrel rabolták ki az Óbudai Közért bevételét feladni szándékozó alkalmazottakat. ${ }^{43}$

Gödöny József: Nemzetközi erőfeszítések a búnözés visszaszorítására. Jogtudományi Közlöny, 30. (1975), 9. 500 .

Heti Híradó, 21. (1977), 15. 3.

Nemzeti Emlékezet Bizottsága: Az 1945-1988 között magyar bíróságok ítélete alapján kivégzettek.

50-130/1978. BM ORFK I-1. Osztály Intézkedési Terve. (ÁBTL- 4.2-50-130/1978.)

Konczer István 1979. december 14-ei összefoglaló jelentése a nyomozásról, 80. 
Májusban, a Fejér megyei Söréd mellett egy hamisított rendőrségi rendszámmal ellátott, lopott Zsigulival, rendőrségi intézkedést színlelve megállították a Magyar Posta pénzszállító autóját, majd a gépkocsivezetőt és a kísérőt fegyverrel fenyegetve, illetve erőszakkal a raktér kinyitására kényszerítve az ott tárolt értékeket eltulajdonították. Az elkövetéshez használt gépkocsit Győrtől nem messze felgyújtották. A három elkövetőt végül augusztusban elfogták, majd a bíróság őket 6, 7 és 8 év fegyházbüntetésre ítélte. ${ }^{44}$

Márciusban egy 5 hónapos betöréssorozat ért véget, miután elfogták a Vértes György vezette 14 fős csoportot, akik mintegy 30 betörést követtek el. Profikhoz illően bérelt autókkal jártak, hasábrádiókkal tartottak kapcsolatot, és gáz-riasztófegyverrel rendelkeztek, amelyet esetleges elfogásukkor készek lettek volna használni is. ${ }^{45}$ Vértes az elfogása előtt 5 hónappal szabadult a korábban kiszabott 7 év 4 hónapos börtönbüntetéséből, és elfogása után pár hónappal már a börtönőrt megtámadva próbált meg ismét megszökni, ami ekkor nem sikerült neki. Később, 1982 augusztusában Szegedről mégis megszökött, és egy újabb betöréssorozatba kezdett. Ennek során további 26 betöréssel 6 millió Ft-nyi értéket zsákmányolt. Végül 4 hónap rejtőzködés után Óbudán a rendőrök felismerték és tűzpárbajt követően újra elfogták. ${ }^{46}$

Április 9-én az Úttörővasút (mai Gyermekvasút) hárshegyi megállójánál a büntetett előéletű, 32 éves Molnár Henrik megölt egy 13 éves lányt, és súlyosan megsebesítette a vele lévő 15 éves fiút. Értelmetlen tettét követőn nem sokkal feladta magát a rendőrségen. ${ }^{47}$ Molnárt a bíróság halálra ítélte, és a bűntett után 8 hónappal, 1979. december 6-án kivégezték. ${ }^{48}$

1979 júliusában, a fővárosban egy gyújtogatássorozat kezdődött, amelynek elkövetője több szállodában okozott tüzet. A több szállodát, illetve a Vidámparkot érintő sorozat legsúlyosabb esete augusztus 10-én történt a Hotel Duna Intercontinentalban, amelynek során egy alkalmazott is meghalt, és 25 millió Ft-os kár keletkezett. A tüzesetek 1980-ban is folytatódtak, majd a 25 éves elkövetőt az augusztus 31-ei margitszigeti gyújtogatás után fogták el, a veszélyeztetett helyszínekre szervezett figyelőszolgálat és akció eredményeként. A nyomozás során 10 szállodai tűzokozást beismert, de ezenfelül 113 - épületben vagy közintézményben elkövetett - gyújtogatást is rábizonyítottak. ${ }^{49}$

1979 nyarán aztán újabb, az egész országot megdöbbentő bűntény történt. Mint utólag kiderült, egy fegyveres rablásra készülő, és korábban már több embert meggyilkoló bűnözői társaság megölte a rendőrként szolgálatot teljesítő - később

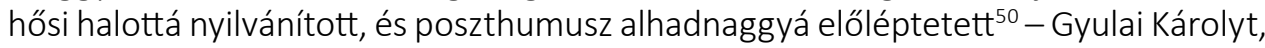
majd holttestét a közelben elásták.

Dunántúli Napló, 36. (1979), 280. 4.

Konczer István 1979. december 14-ei összefoglaló jelentése a nyomozásról, 2.

Magyar Hírlap, 18. (1985), 113. 4.

Dolgozók Lapja, 32. (1979), 213. 8.

Nemzeti Emlékezet Bizottsága (é. n.) i. m

Tóth Ferenc - Kétyi Károly: Szállodai tűzesetek nyomozása. In Korinek László - Finszter Géza (szerk.): 60 év, hatvan büncselekmény II. Budapest, Belügyi Szemle, 2012. 20-23.

50 13/1979. (VII. 26.) számú belügyminiszteri parancs. (ÁBTL- 4.2-10- 22/13/1979.) 


\section{Gyulai Károly rendőr főtörzsőrmester meggyilkolása ${ }^{51}$}

1979. július 10-én, hajnali fél ötkor munkatársai nem találták a szolgálati helyén - a fővárosból kivezető Vörös Hadsereg útja ${ }^{52}$ végén, a Steinmetz-szobornál lévő 5 . számú útelzáró őrhelyen - Gyulai Károly rendőr főtörzsőrmestert. Vele együtt eltűnt az RK-59 típusú szolgálati pisztolya is, amelyhez $2 \mathrm{db}$ tár és $10 \mathrm{db}$ lőszer tartozott. Az eltûnés észlelését követően a Budapesti Rendőr-főkapitányság (BRFK) Bűnüldözés Osztály munkatársai átvizsgálták az őrhelyet és környékét, de akkor érdemleges adat vagy nyom nem került elő. Annyit azonban sikerült megállapítani, hogy a szolgálati géppisztolya a teli tárral, az esőkabátja és az iratai az őrbódéban maradtak. A Meteorológiai Intézet tájékoztatását és a hátramaradt esőkabátot figyelembe véve az eltűnését 02:00 óra előttre vélelmezték.

A járőrt megbízható, lelkiismeretes rendőrnek ismerték, így már az első perctől felmerült, hogy a sérelmére súlyos bűncselekményt követtek el. Konkrét adat hiányában azonban a nyomozást másnap még kötelességszegés szolgálatban vétség gyanúja miatt kellett elrendelni, aminek keretében lehetőség nyílt az őrhelyen és környékén helyszíni szemlét tartani. Az előző napi esőtől nedves aszfalt időközben száradni kezdett, és az őrhelytől 36 m-re, a Budapest felé lévő villanyoszlopnál, az úttest melletti padkáról Gyulai Károly vércsoportjával megegyező vérnyomot rögzítettek.

Meggyilkolásának addig is fennálló sajnálatos gyanúja ezzel még erősebbé vált, így minden lehetséges erőt a felderítésre koncentráltak. Párhuzamosan folyt az adatgyüjtés, a tanúkutatás az őrhely mellett a feltételezett időben elhaladó autók azonosítása és az azokban utazó személyek kihallgatása érdekében, illetve a terepkutatás a vélelmezett holttest megtalálására.

Az eltűnést követő második napon, július 12-én délben a Vecsés melletti mezőgazdasági területen, az őrbódétól 8,7 km-re, az oda beosztott kutatócsoport egy nagyobb kiterjedésú vértócsát, illetve annak közelében vonszolási nyomokat fedezett fel. Ennek irányában tovább haladva, a kukoricásban egy $2 \mathrm{~m}^{2}$ nagyságú, lazább szerkezetű, nemrég felásott földterületet találtak, amelybe a kukoricaszárakat ugyan visszaültették, de azok száradni kezdtek. A helyszínre irányított szemlebizottság megkezdte a talajrész átvizsgálását. Ennek során mintegy 60-70 cm mélyről előkerült a meggyilkolt Gyulai Károly holtteste, akinek halálát fejre mért ütések, illetve a nyak átvágásából eredő kivérzéses sokk okozta.

Az alapos, mindenre kiterjedő szemle során az elhantolás helyén több lábnyomot, cigarettacsikket, a holttest ruházatáról pedig bordó színú festékmaradványt rögzítettek. A vonszolási útvonalon egy levált cipőtalp-darab, míg a környező területről egy vérrel szennyezett Wartburg-féltengely és egy szintén véres, zöld színű nadrágdarab került elő. A tágabb területen végzett kutatás során, az elrejtés helyétől körülbelül 500 m-re, a bizottság még egy véres nyelű, korábban betonozáshoz használt ásólapátot is talált.

A nyomozás bemutatása Konczer István 1979. december 14-ei, illetve Kacziba Antal 1979. december 19-ei jelentése alapján történt.

Ma Budapest, XVIII. kerület, Üllői út. 
A földúton, a vérszennyeződés helyén - az ott rögzített keréknyomok alapján - egy keleti gyártmányú, valószínúleg Lada, Polski Fiat, Wartburg vagy Moszkvics típusú gépkocsival fordultak meg.

A további szakértői vélemények szerint a féltengelyen, a nadrágon és a lapáton lévő vér megegyezett Gyulai Károly vércsoportjával, továbbá a súlya és alakja szerint a féltengellyel okozhatták a fejsérüléseket. A lábnyomok alapján az elkövetők legalább hárman voltak.

A felkutatott egyik tanú vallomása szerint az eltűnés napján 01:45 óra körül az őrbódétól nem messze - a padkán talált vérnyommal megegyező helyen - egy sötétbordó színú gépkocsit látott, amelynek hátsó motorháza vagy csomagtartója nyitva volt, amibe három férfi hajolt be, míg a rendőr az őrhelyétől az úttest mellett gyalogolva oda közelített. A tanú a kocsit Skodának vélte. Mint utólag kiderült, ebben az egyben tévedett, de ténylegesen az elkövetőket látta.

Ezenkívül több tanú látott a környék több pontján (Vecsésen, Ecseren és a XVIII. kerületben) a bűncselekmény éjszakáján egy bordó vagy piros színú, I-vel kezdődő rendszámú Zsigulit (vagy ahhoz hasonló kinézetű autót) 2-3 fővel közlekedni vagy várakozni.

A szakmai és a politikai vezetés kiemelten kezelte a gyilkosság felderítését, és minden lehetséges erőt erre összpontosított. Már az első napon felsővezetői eligazításra került sor, amely során dr. Ladvánszky Károly rendőr vezérőrnagy, miniszterhelyettes meghatározta a nyomozás szervezésének, teljesítésének főbb irányait, valamint az azokban érintett szervek együttmúködésének rendjét. A nyomozás egyik irányítója, dr. Vedres Géza erre így emlékezett: „A nyomozás irányítása az ORFK bűnügyi csoportfőnökségének hatáskörébe került. Az egymással határos, de elkülönített illetékességű rendőrhatóságok, valamint a központi osztályok, a bűnügyi állomány felderítő munkájának összefogása, koordinálása és irányítása is ezt igényelte. Már a nyomozás elrendelése előtti intézkedések szélesedő köre megkívánta, hogy nagy létszámú egységeket vonjunk be a felderítésbe. Egyértelművé tettük az együttmüködők közötti alá- és fölérendeltséget." ${ }^{53}$

A BRFK ez alapján két nappal később, július 13-án személyes eligazítás keretében ismertette a nyomozás részletesebb feladattervét az érintett vezetőkkel. A nyomozás során két irányítási pontot állítottak fel: az egyik, 120 fővel a BRFK-n, míg a másik, 60 fős egység Pest megyében. Ez a helyszínhez közeli vezetési struktúra megegyezett Déri Pál - későbbi publikációiban is megjelent ${ }^{54}$ - szakmai álláspontjával, amelyet Finszter Géza így foglalt össze: „[A] felderítő beavatkozás az elkövetés helyéhez legközelebb, az elkövetés időpontjához képest a legkevesebb időveszteséggel történjék, mégpedig olyan módon, hogy a bünüldözés a legmagasabb szakértelmet és technikai készültséget mozgósítsa." 55

Hat nappal a rendőrgyilkosság után, július 16-án a nyomozásban újabb jelentős esemény történt. Egy ismeretlen nő az elkövetők által megszerzett pisztolyt és tárakat

\footnotetext{
53 Vedres Géza: Rendőrgyilkosság az 5. számú őrhelyen. In Korinek László - Finszter Géza (szerk.): 60 év, hatvan büncselekmény II. Budapest, Belügyi Szemle, 2012. 13.

54 Déri Pál: Az állam és a társadalom kötelezettségei a bűnözés elleni harcban. In Bócz Endre (főszerk.): Kriminalisztika. II. Budapest, BM, 2004. 925-968.

55 Finszter Géza: A kriminalisztika ígérete. Magyar Tudomány, 181. (2020), 5. 601.
} 
a Budapest XVIII. kerületi SZTK ${ }^{56}$ női mosdójában megtalálta, a portásnak leadta, majd távozott. A bejelentés után a rendőrség rövid időn belül lezárta a környéket, és 173 főt igazoltatott. Ennek alapján a fegyvert elrejtő személyt ugyan nem, de a fegyvert megtaláló nőt sikerült pár nap után azonosítani. A 73 éves nő az első igazoltatáskor a szerepét elhallgatta, és csak a két nappal későbbi ismételt kihallgatásakor ismerte el. Izgalmat keltett, hogy a megtaláló fia szándékos emberölés miatt volt korábban büntetve, de az ellenőrzések során kizárták a lehetséges elkövetői körből.

Az elsődleges adatok alapján felállították az elkövetők „profilját” is, amelynek megállapításai utólag helyesnek bizonyultak:

- gyors mozgású, jó fizikumban lévő, agresszív férfiakból álló, legalább 3 fős csoport;

- Ecseren, Vecsésen vagy a XVIII. kerületben laknak, vagy ott rendszeresen megfordulnak, és közeli ismerősökkel rendelkeznek;

- rendszeresen használnak, esetleg a tulajdonukban is van gépkocsi;

- legalább az egyikük Fecske cigarettát szív;

- durva, kíméletlen, köztörvényes bünözők.

Az indítékok közül a politikai motívumot - a holttest elrejtése, a végrehajtás leplezett módja miatt - elvetették; és legerősebb verziónak a fegyverszerzés, vagy egy másik bűncselekmény leleplezésének megakadályozása maradt meg. A nyomozás során több vonalon, széles körü adatgyűjtés folyt:

- Az őrhely mellett elhaladó közúti és vasúti forgalom folyamatos ellenőrzésével megkíséreltek olyan tanúkat felkutatni, akik a bűncselekmény éjszakáján arra jártak, és esetleg észleltek valamit. A 4-es főút érintett szakaszán 28 napig, naponta 00:00 és 04:00 óra között végrehajtott adatgyüjtés során 120-150 autót és azok 150-280 vezetőjét, utasát igazoltatták naponta, ami végül több ezer személyi és rendszámadatot eredményezett.

- A helyszín közelében lévő építkezések és egyéb állami vállalatok dolgozói közül 8472 fő ellenőrzése, illetve a távolabbi vállalatok közelben lévő munkásszállóin élő 891 személy ellenőrzése vált szükségessé.

- 5 évre visszamenőlegesen kigyűjtötték a Gyulai Károly és váltótársa intézkedéseivel kapcsolatos jelentéseket, az esetleges bosszúmotívum ellenőrzése érdekében.

- Az érintett településeken (Vecsésen, Ecseren, Üllőn, Maglódon, Gyálon, illetve a XVIII. kerületben) házról házra jártak a nyomozók. Ennek során több száz rendőr és munkásőr mintegy 180 ezer személyt hallgatott meg, és rögzítették az általuk elmondottakat.

- Az SZTK-nál igazoltatott 173 fő mellett kigyújtötték a rendelőben kezeltek adatait is. Elsőként a július 16-án kezelt 460 fő, majd további lépésként 4 évre visszamenőleg további 103 ezer női beteget, illetve 264 aktív és 46 kilépett egészségügyi dolgozót azonosítottak, és megkezdték ellenőrzésüket.

Szakszervezeti Társadalombiztosítási Központ, ami az állami egészségügyi ellátás intézményrendszere volt ebben az időben. 
- Leválogatták a felmerült típusú gépkocsik (például Wartburg, Moszkvics, Zsiguli, piros színúek, I-vel kezdődő rendszámúak) adatait, majd megkezdődött tulajdonosaik ellenőrzése, elszámoltatása és indokolt esetben a gépkocsik technikusi vizsgálata. Ennek során több ezer (személy)gépjármú került látókörbe. Az ellenőrzés volumenét mutatja, hogy csak a XVIII. kerületben a nyilvántartott 9542 gépkocsiból közel 3000 gépkocsi részletesebb, technikus igénybevételével történő ellenőrzésére és vizsgálatára került sor.

- Ellenőrizték a visszaeső, erőszakos bünözőket. A modus operandi nyilvántartásban végzett kutatás eredményeként összesen 594 fő került látókörbe, akik közül 69 fő korábban lőfegyver megszerzésére törekedett, 10 fő úgy követett el emberölést, hogy az áldozatát elásta, illetve Pest megye kérdéses részén 51 fő követett el 1975 után dolog vagy személy elleni erőszakkal bűncselekményt.

- Kiértékelték a korábbi nyomozások, operatív felderítések adatait, különösen, ahol lőfegyver megszerzése vagy azzal tervezett büncselekmény merült fel.

- 1979. augusztus 29-én a televízió Kékfény címú adása részletesen beszámolt a bűntényről, és a lakosság segítségét kérte, ami több száz, ellenőrzésre érdemes bejelentést eredményezett.

A kiterjedt nyomozás pár hónap alatt meghozta az eredményt. Egy július végi bejelentés alapján került látókörbe a Vecsésen lakó, 36 éves, többszörösen büntetett Soós Lajos, aki 3-4 évvel korábban egy kocsmai beszélgetésnél már tervezte a Steinmetzszobornál posztoló rendőr fegyverének erőszakkal történő megszerzését.

Soós részletesebb ellenőrzése során megállapították, hogy már korábban is felmerült a gyanú vele kapcsolatban az ügyben, és ellenőrizték is. Július 14-én egy taxi utasa felhívta rá a figyelmet, mint aki egy bordó Polski Fiattal rendelkezik, és erőszakos cselekményekre hajlamos. Az általa használt IH 45-32 rendszámú Polski Fiatot ez alapján már a nyomozás 7. napján megvizsgálták, de első körben kizárták a további ellenőrzésre szorulók köréből. Bár az alibije kétségeket ébresztett, a szakértői vélemény a gépkocsiból rögzített vérnyomot és festékmintát nem értékelte relevánsnak.

Soós időközben munkahelyet váltott, de megállapították, hogy a volt munkahelye bélyegzőjével és munkatársától lopott igazolvánnyal június 14-én saját magának vásárolt alkatrészeket. Ugyancsak értékes információ volt, hogy július 16-án, azaz a fegyver elrejtésének napján orvosi felülvizsgálaton kellett volna megjelennie a kérdéses SZTK-ban, amit elmulasztott.

A célirányos felderítés közben, augusztus 21-én Soósra egy újabb bejelentés érkezett, amely szerint ő a rendőrgyilkoság egyik tettese, és mivel erről a telefonáló is tudott, ezért őt életveszélyesen megfenyegette. Emellett információt adott arról is, hogy Soós 1972-ben egy Józsi nevű társával Törökbálinton is megölt egy idős nőt, amiről állítása szerint korábban már tett bejelentést.

A telefonhívás ellenőrzése érdekes eredményt hozott. Törökbálinton 1972. november 3-án a lakásában holtan találták a gyilkosság áldozatául esett 65 éves Farkas Józsefnét, és értékeinek egy részét a lakásból eltulajdonították. A nyomozás eredménytelen maradt, de 1979 júniusában valóban érkezett egy bejelentés az ügyben Soós Lajosra és egy József nevű személyre vonatkozóan, amit addig érdemben még nem ellenőriztek. A bejelentés valóságtartalmát erősítette, hogy az áldozat egyik 
szomszédjában Soós feleségének a szülei laktak. Mint utólag kiderült, ők tudtak is Soós szerepéről, de erről korábban nem mertek bejelentést tenni a lányuk védelme érdekében.

Az adatgyújtések és az operatív intézkedések eredményeként a felesége mellett rövid időn belül azonosították Soós többi bűntársát is; a 30 éves Mester Jánost, a 38 éves György Józsefet és a 20 éves Németh Istvánt, akikkel rendszeresen követett el gépkocsifeltöréseket, lakásbetöréseket.

Augusztus 31-én sikerült a Soós által használt Polski Fiatot Tatabánya közelében ismételten ellenőrizni, és tüzetesebb szakértői vizsgálat alá vonni. Ennek eredménye már biztatóbb volt. A csomagtartóban több rétegben találtak festéket, amelyek között előfordult az áldozat ruhájáról rögzített, Neolux 830 típusú is.

A beszerzett adatok alapján először 1979. szeptember 26-án Mester Jánost, utána október 1-jén Soós Lajosnét fogták el, és vették őrizetbe lopások miatt. Október 3-án a REF ${ }^{57}$-szabályok megsértéséért 30 napos elzárással sújtották György Józsefet, majd október 8-án összehangolt akció keretében elfogták Németh Istvánt és Soós Lajost. Így gyakorlatilag alig két hét alatt a rendőrség őrizete és felügyelete alá került a teljes gyanúsítotti kör.

A jól előkészített kihallgatási taktika, és a korábban beszerzett adatok hatására először Németh István tett érdemi vallomást. Október 18-án a vagyon elleni bűncselekményeken túl beismerte, hogy Soóssal és Györggyel közösen ők követték el a rendőrgyilkosságot.

Ezen túl vallomást tett egy másik emberölésről is, amelyet 1979. június 23-án követett el Soós Lajossal. A későbbi áldozattal, a gyermeke születését ünneplő 23 éves Borai Lajossal egy közeli kocsmában ismerkedtek meg, ahonnan gépkocsival közösen indultak tovább. Útközben összeszólalkoztak, és a kocsiból kiszálltak. Soós előbb ütlegelni kezdte Borait, majd egy késsel átvágta a földön fekvő áldozata nyakát. Felszólítására Németh is többször mellkason szúrta a számukra ismeretlen férfit, és elvették értékeit. A holttestet előbb az úttest mellett hagyták, de hajnalban úgy döntöttek, hogy távolabb rejtik el. Ezért kocsival a közel 100 km-re lévő Tiszapüspöki mellé szállították, és ott ásták el. A nyomozás során elvégzett helyszíni kihallgatások után itt hantolták ki és azonosították az addig eltűntként keresett férfit.

György István október 19-én jelentkezett kihallgatásra, amely során a Soóssal közösen elkövetett 1972-es törökbálinti emberölést, illetve Gyulai Károly meggyilkolását ismerte el, amiben vallomása szerint rajtuk kívül még Németh is részt vett.

A társak után október 23-án Soós Lajos is beismerő vallomást tett, amiben újabb meglepetéssel szolgált. Az addig felmerült három emberölés mellett további két újabb gyilkosságot ismert be, amelyeket egy régebbi bűntársával, a 35 éves Varga Lászlóval követett el. Az első, 1963-ban elkövetett emberölés áldozata egy korábbi munkatársa volt, akivel előzőleg közösen követett el betörést. Mivel félt attól, hogy egy esetleges lebukás esetén magával rántaná, Varga László tanácsára a likvidálásáról döntött. Soós és Varga az áldozatot - akit csak „Pista” néven ismertek - augusztus

57 Rendőrhatósági felügyelet: az 1/1957. (III. 19.) BM számú rendeleten alapuló, legfeljebb 2 évig tartó hatósági kényszerintézkedés, amely meghatározott magatartási szabályokat (például egyes szórakozóhelyek látogatási tilalmát, lakás vagy lakóhely elhagyásának tilalmát, rendőrségen való időszakos bejelentkezési kötelezettség) írt elö, és amelynek megszegése elzárással volt büntethető. 
első napjaiban a Duna budai oldalán, a Szabadság híd közelében fürdésre beszélték rá, majd a folyóból már nem engedték kimászni. Soós a vallomása szerint többször visszalökte, majd egy arra elhaladó hajó hullámai között végleg elmerült.

1979-ben a Soós által közölt adatok (munkahely, becsült életkor, lakóhely) alapján a vélt áldozatot Moskolák Istvánként azonosították, aki 1963. augusztus elején, 23 évesen tűnt el. Róla azóta semmilyen adat nem keletkezett, életjelet nem adott magáról.

Valószínúleg Soósék áldozatát emelték ki a Dunából 1963. augusztus 17-én. Ekkor a folyó pesti oldalán, a Belgrád rakpart magasságában találták meg egy fiatal, 15-25 év körüli férfi holttestét, aki valamivel több, mint 1 héttel korábban fulladt vízbe. Sem a személyazonosságát, sem az idegenkezúséget nem tudták megállapítani, így nyomozás lefolytatása nélkül, ismeretlen halottként temették el. 1979-ben megkísérelték az azonosítást, de az exhumálás során a koponya nem került elö, így - az akkor rendelkezésre álló módszerekkel - nem tudták azonosítani. Ennek hiányában az ügyészség nem emelt vádat Soós és Varga ellen.

A másik, addig látenciában lévő emberölést Soós és Varga 1968. május 15-én, az akkor 24 éves Pataki Károly pénzügyőr őrmester sérelmére követte el. A Varga ismeretségi körébe tartozó áldozatot egy közös italozást követően Soós vecsési lakására csalták. Pataki az alkohol hatására elaludt, és ezt kihasználva Soós megszerezte a kulcsait, majd a XIII. kerületben lévő Kádár utcai lakásából ellopta szolgálati fegyverét. Visszaérkezése után eldöntötték, hogy Pataki nem maradhat életben, így álmában baltával többször fejbe vágták, majd nyakát átmetszették, és a holttestet a vecsési ház udvarán elásták. A lebukástól való félelmükben a fegyvertől végül anélkül szabadultak meg, hogy azt használták volna.

Patakit - aki korábban megpróbált Nyugatra szökni - egy ideig eltűntként körözték, majd felesége 1973-ban holttá nyilváníttatta, és körözését visszavonták. Holttestét Soós vallomása alapján 11 év múlva, 1979. október 24-én hantolták ki, amelynek azonosításához a hazai kriminalisztikában először alkalmazták a szuperimpozíciós eljárást. A módszer az arckoponyacsont és az arc azonosításra alkalmas - fényképről elvégezhető - összehasonlíthatóságán alapul, amelyről azóta már „A halottvizsgálatról és a halottakkal kapcsolatos eljárásról” szóló 351/2013. (X. 4.) Korm. rendelet 22. § (3) bekezdése is rendelkezik.

Soós vallomása alapján Vargát másnap, október 25-én fogták el, aki az első kihallgatásán tagadta az emberölést. Két hónappal később annyit változtatott, hogy valóban jelen volt a pénzügyőr megölésénél, de állítása szerint abban tevőlegesen nem vett részt. A kihallgatások során a Moskolák István sérelmére elkövetett emberölést nem érintették, azzal kapcsolatban nem vonták felelősségre.

A nyomozás adatai szerint Soós már évek óta készült a rendőrgyilkosságra. Az elkövetés napján az előzetes megbeszélés szerint Soós, Németh és György nem sokkal éjfél után érkeztek a bordó Polski Fiattal a Steinmetz-szobor közelébe. Itt megvárták, míg elcsendesült a környék, majd az őrbódé közelében múszaki hibát színleltek. Ahogy számítottak rá, a segítőkész Gyulai Károly hozzájuk lépett, és felajánlotta elemlámpáját, amiért visszament a bódéhoz. Miután visszaért, a csomagtartóba hajolva közösen próbáltak meg izzót keresni, miközben Soós a magánál tartott féltengellyel leütötte. Az eszméletlen - és általuk halottnak hitt - testet a csomagtartóba tették, mialatt 
Németh elszaladt az őrhelyhez a géppisztolyért. Idegességében nem találta meg, így anélkül hajtottak el a helyszínről, Vecsésen át Ecser irányába. Útközben a csomagtartóból meghallották a rendőr nyöszörgését, így a kocsival félreálltak, és Soós ismét több ütést mért a fejére. Soós javaslatára a közeli mezőgazdasági területre hajtottak, ahol a testet kiemelték a csomagtartóból, és a rendőr nyakát a zsebkésével átvágták. Egy előző nap lopott ásóval a kukoricásban gödröt ástak, és ide temették el. Az ásót és a féltengelyt a közelben eldobták. Ezután Vecsésre mentek, ahol Soós a lakásán átöltözött, megtisztította a kocsiját, majd száraz ruhát vitt a közeli temetőben megbúvó, és a szakadó esőben bőrig ázó Némethnek és Györgynek.

A fegyvert először a közeli erdőben rejtették el, majd azt pár nap múlva elővették, és Soós - a vallomása szerint - elrejtette az SZTK-ban. Utóbbi állítását nem lehetett cáfolni, de a nyomozók meggyőződése maradt, hogy azt valójában a bűncselekményeiről tudó édesanyja tette a női WC-be, és Soós őt mentette.

A bíróság végül Soós Lajost és György Józsefet halálra, Németh Istvánt 20 év, ${ }^{58}$ Varga Lászlót 15 év fegyházbüntetésre, míg a vagyon elleni bűncselekményekben érintett további társaikat rövidebb tartamú szabadságvesztésre ítélte. ${ }^{59}$ Soós és György kivégzését - nem egészen egy évvel az elfogásuk után - 1980. október 1-jén végrehajtották. ${ }^{60}$

\section{A nyomozás informatikai támogatása}

A végső statisztikai adatok szerint az elkövetők elfogásáig a közel 200 ezer meghallgatott személyből 12 ezer szoros elszámoltatását, illetve a 23 ezer ellenőrzött gépkocsiból 14 ezer technikusi vizsgálatát hajtották végre.

A nyomozás során napról-napra egyre több adat, információ keletkezett, amelyek relevanciája akkor még nem volt megítélhető. Félő volt, hogy egy elfelejtett vagy nem kellően ellenőrzött adat a nyomozást félreviszi, zsákutcába tereli.

Ez a félelem nem volt alaptalan. Mint utólag kiderült, az emberölést elkövető Soós Lajost és az általa a gyilkossághoz is használt gépkocsit már a nyomozás 7. napján megvizsgálták. Az első körös ellenőrzésben kizárták, és személye csak egy későbbi bejelentést követően vált ismét érdekessé. Emellett Soós neve már a törökbálinti emberölésnél is felmerült, de a részinformációk nem álltak össze teljes képpé.

Az egyes vonalakon már olyan mennyiségú információ keletkezett, amelynek teljes körű feldolgozása meghaladta az emberi agy kapacitását. A nyomozásban részt vevő Kacziba Antal ezt így fogalmazta meg: „A bizonyítékok és a bizonyító tények - együttesen a nyomozás során szerzett információk - mennyisége egy bizonyos szinten túl veszít informatív értékéből. Egyszerűen arról van szó, hogy olyan mennyiségű adat keletkezik, melynek rendszerezése, elemzése, értékelése meghaladja az emberi agy kapacitását. Így fennáll annak veszélye, hogy a nyomozás során keletkezett értékes

Németh az elkövetéskor nem töltötte be a 20. életévet, így nem lehetett halálra ítélni.

Szűcs Gábor: Jogerős ítéletet hirdettek a rendőrgyilkosok ügyében. Esti Hírlap, 25. (1980), 213. 8.

Nemzeti Emlékezet Bizottsága (é. n.) i. m. 
információk szétszóródnak, vagy a vonalak és területek szerint is széttagolt nyomozásban nem hozhatók egymással összefüggésbe."61

A belügyi vezetés már az első hetekben elfogadta az ORFK Vizsgálati Osztály javaslatát, ${ }^{62}$ ami egy adatfeldolgozási információs rendszer alkalmazását kezdeményezte. A javaslat nem volt teljesen új keletü. Déri Pál 1976-ban a Korszerü nyomozás - integrált bünüldözés címü könyvének VII. fejezetében, A Tájékoztató és Koordinációs Központ bekapcsolása a helyszínes büncselekmények felderítésébe címmel az elképzelés alapjait már kidolgozta. ${ }^{63}$

Bünügyi nyomozás ilyen jellegű támogatására korábban a hazai kriminalisztikában nem volt példa. Ugyan Fejér megyében egy jelentős sikkasztási ügyben, illetve a Hungária körúti OTP-ben elkövetett kettős gyilkosság felderítésénél már felmerült ennek az igénye, de akkor ez részben a számítástechnikai eszközök, részben az adatrögzítő és feldolgozó kapacitás hiánya miatt nem valósulhatott meg.

Az elfogadott javaslat alapján az ORFK Vizsgálati Osztálya és a BM AFCS közösen, bűnügyi szakemberek, elemzők és informatikusok bevonásával alakította ki a rendszert, amely a Déri Pál könyvében szereplő Tájékoztató és Koordinációs Központ (TKK) nevet kapta. Az ide bejuttatott és feldolgozott adatokat számokká kódolták, majd ezeket rögzítették, és így kereshetővé váltak. A rendszer kialakításában jelentős szerepet vállalt dr. Kunos Imre is, akinek 1997-ben készült Bünelemzés című tanfolyami jegyzete képezte a bűnelemzésről szóló első ORFK utasítás ${ }^{64}$ alapját is.

A nyílt nyomozás és az operatív felderítés iratai (a jegyzőkönyvek, a rendőri jelentések, az igazoltatások és ellenőrzések adatai, a bejelentések és minden más dokumentum) másolatban kerültek át a TKK-hoz, ahol a feldolgozás alapbizonylatai lettek.

Az első lépcsőben ezeket az értékelőtisztek olvasták át, akik aláhúzással jelölték ki a lényegesnek tartott részeket. Kezdetben ezt a feladatot két tiszt végezte, majd a létszám négy főre bővült.

A feldolgozást nehezítette, hogy a munka kezdeti lépéseként - mivel ez csak pár héttel a nyomozás kezdete után indult be - az addig keletkezett adatokat is fel kellett dolgozni, a párhuzamosan érkező friss anyagokkal együtt.

A következő lépés az adatok kódolása volt, ami lehetővé tette a számítógépre történő rögzítésüket, feldolgozásukat és keresésüket. Ezt egy 20 fős kódolócsoport végezte, amelynek irányítója a TKK vezetőjének közvetlen alárendeltségébe tartozott. A csoporton belül 16 fő végezte a kijelölt adatok kódolását, míg 4 fő kódellenőrként felügyelte azok helyességét. A csoport tagjait a Rendőrtiszti Főiskola bűnügyi szakos hallgatói állományából vezényelték, 8 munkanapos váltásokban.

$61 \quad$ Kacziba Antal 1979. december 19-én kelt jelentése a Tájékoztató és Koordinációs Központ szervezésének és az információk a számítógépes feldolgozásának tapasztalatairól, 2.

62 Kacziba Antal által készített, és Katona Géza által jóváhagyott, 1979. augusztus 7-én kelt javaslat a nyomozás során keletkezett adatok számítógépes rendszerezésére.

63 Déri Pál: Korszerű nyomozás - integrált bűnüldözés. Budapest, BM Tanulmányi és Propaganda Csoportfőnökség, 1976. 201-268.

64 13/2001. (X. 2.) ORFK utasítás a Magyar Köztársaság Rendőrsége Bűnelemzési Szabályzatának kiadásáról. 


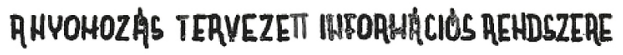

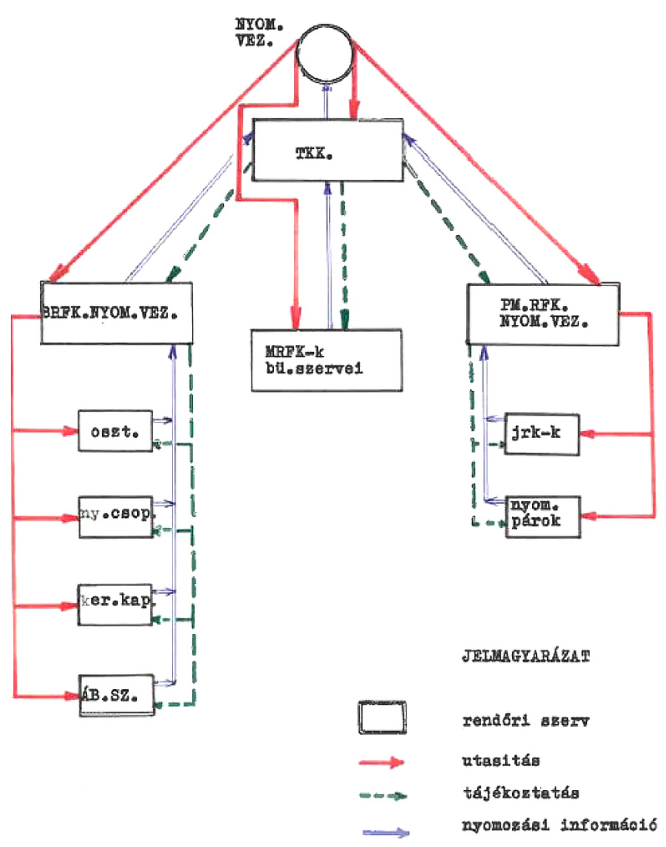

3. ábra

A nyomozás tervezett információs rendszere

Forrás: Kacziba Antal 1979. december 19-ei jelentése

A kódoláshoz szükséges 58 oldalas kódszótár összeállítása a rendkívül szűk határidő miatt nem lehetett teljes körü és végleges. A munka során sok olyan fogalom merült fel, amely még nem szerepelt kódszótárban. Ennek megoldására az egyes fogalomcsoportok (személy, dolog, esemény-körülmény) végén a készítők hagytak olyan tartalék kódszámokat, amelyekhez nem tartoztak még meghatározások. új fogalom felmerülése esetén a kódoló ezt jelezte a csoportvezetőnek, aki egyrészt azt bevezette a következő üres helyre, másrészt intézkedett arról, hogy a használatban lévő összes példányra felvezessék. Ez a gyakorlatban a példányok egyenkénti, kézzel történő kiegészítését jelentette minden alkalommal.

Az információkat az alapbizonylatok típusa, illetve tartalmuk alapján az ötféle adatlap valamelyikén rögzítették. Az adatlapok közül az „A” típusú magával az alapbizonylattal, az „E” az eljárásban ellenőrzött személlyel, a „C” a releváns (őrhely, a holttest elrejtési vagy a fegyver megtalálási) helyszínnel, a „K” az áldozathoz vagy valamely 
dologhoz füződő kapcsolódással, az „S” az ügyben ellenőrzött személy ismert vagy ismeretlen releváns kapcsolatával összefüggő információkat tartalmazta. ${ }^{65}$

A feldolgozás végén kinyerhető adatokat a felhasználók, azaz a nyomozók és a nyomozás vezetőinek igényeihez igazították. Ez alapján a lekérdezésekkel:

- gyors és pontos válasz érkezett arra a kérdésre, hogy személyek vagy gépjármüvek szerepelnek-e az adattárban, és ha igen, milyen adatokkal, melyik dokumentumban;

- egyszerüsödött az információk egymáshoz rendelése;

- lehetővé vált az elvégzett tevékenység statisztikai módszerekkel történő mérése.

Az egyszerű priorálás mellett megteremtették a kombinált, szűrőfeltételes keresés lehetőségét is. Összesen 250 jellemzőt lehetett beállítani, amelyeket csoportokban (például személy, dolog, helyszín, körülmény, időpont) kezeltek. Ezzel olyan kérdésekre tudtak az adatbázisból rövid időn belül, megbízható választ adni, mint például: „Kik azok a 35-40 év közötti, Vecsésen lakó, piros gépkocsival rendelkező férfiak, akik korábban Pest megye területén elkövetett erőszakos büncselekmény miatt voltak büntetve?"

A lekérdezésre adott válasz nyomtatott formában jutott el a felhasználókhoz, akik részletesebb adatokat az eredeti dokumentumból az alapbizonylat azonosítószáma alapján tudhattak meg. A TKK működését és hasznosulását teljeskörűen nem lehetett értékelni, mivel az elkövetőket még azelőtt sikerült felderíteni, mielőtt az összes adatot feldolgozták volna. Ezzel együtt a belügyi vezetés megértette, elfogadta a bünelemzés, az adatfeldolgozás informatikai segítésének fontosságát, és hosszú távon is támogatta azt. Egyértelmüvé vált, hogy a földrajzi és szervezeti értelemben is széttagolt, kiterjedt intézkedésekkel járó, nagy mennyiségű adatot eredményező nyomozásokban már nem érvényesek a klasszikus nyomozásirányítási elméletek és módszerek. A TKK létrehozása és rövid müködése magában hordozta egy új elvek szerint folytatott nyomozási tevékenység modelljének és információrendszerének alapelemeit.

A munkában részt vevők még ennél is több lehetőséget láttak ebben a rendszerben. Előrevetítették egy új önálló tudomány, a kriminalisztika és az informatika határán megjelenő kriminálinformatika kifejlődését is, amely egyrészt a döntéshozatalhoz szükséges információkat, másrészt a kriminalisztikai kérdések megválaszolását képes támogatni.

A kriminálinformatikától várták volna többek között a nyomozás számítógépre szervezett belső dokumentációs és nyilvántartási rendszerének a kifejlesztését is, amelynek előzetesen a „NYOMDOK” nevet adták. Mint tudjuk, ez ebben a formában nem valósult meg, de az elképzelés az évezred végén a Robotzsaru rendszerként realizálódott. 
A bűnelemzés területén a TKK egy időszerü, a kor technikai vívmányait a lehetőségekhez mérten maximálisan kihasználó újítás volt. A megalkotott alapelvek, a kitűzött célok, valamint az informatika és a kriminalisztika összekapcsolása lehetőséget nyitottak a további fejlesztésére, amely folyamat végén - vagy annak egyik állomásaként - az értékelő-elemző egységek után a 21. században információfúziós központként létrejöhetett a Terrorelhárítási Információs és Bűnügyi Elemző Központ is.

1. sz. melléklet

A nyilvántartásért felelős belügyi szervek és vezetői 1962-1980 között

\begin{tabular}{|c|c|c|c|c|c|}
\hline \multicolumn{2}{|c|}{ Szervezet, beosztás } & Név & \multicolumn{2}{|c|}{ Hivatalban } & Élete \\
\hline \multirow{6}{*}{$\sum_{\infty}$} & belügyminiszter & Pap János & 1961.09. 13. & 1963. 12.07. & 1925-1994 \\
\hline & belügyminiszter & Benkei András & 1963. 12. 07. & 1980.06. 27. & 1923-1991 \\
\hline & államtitkár* & $\begin{array}{l}\text { Rácz Sándor } \\
\text { r. vezérőrnagy }\end{array}$ & 1973. 11.06. & 1974.06. 21. & $1925-$ \\
\hline & államtitkár & $\begin{array}{c}\text { dr. Kamara János } \\
\text { r. ezredes }\end{array}$ & 1974. 06. 21. & 1985. 03. 29. & 1927-2000 \\
\hline & \multirow[t]{2}{*}{$\begin{array}{l}\text { országos rendőr- } \\
\text { főkapitány }\end{array}$} & $\begin{array}{l}\text { Kőrösi György } \\
\text { r. vezérőrnagy }\end{array}$ & 1961. 10. 20. & 1977. 03. 31. & 1922-2005 \\
\hline & & $\begin{array}{l}\text { Ladvánszky Károly } \\
\text { r. altb. }\end{array}$ & 1977. 04. 01. & 1989. 04. 30. & 1928-2014 \\
\hline \multirow{3}{*}{$\begin{array}{l}\frac{v}{u} \\
\stackrel{v}{0} \\
\sum_{\infty}\end{array}$} & II/I-5. (BNYO) & $\begin{array}{l}\text { Ollé Ernő } \\
\text { r. alezredes }\end{array}$ & 1962. 08. 15. & 1964. 12. 31. & 1909-1987 \\
\hline & II/1. (SÉO) & \multirow{2}{*}{$\begin{array}{l}\text { dr. Lázár Bertalan } \\
\text { r. alezredes }\end{array}$} & 1962.08. 15. & 1964. 12. 31. & \multirow[t]{2}{*}{$1927-2000$} \\
\hline & II/1-5. (BNYSO)* & & 1965. 01.01. & 1971. 05. 31. & \\
\hline \multirow{2}{*}{$\underset{\infty}{\stackrel{১}{\doteq}}$} & vezető & $\begin{array}{c}\text { Márkus Sándor } \\
\text { r. alezredes }\end{array}$ & 1962.08. 15. & 1965. 05. 31. & 1920-2007 \\
\hline & vezető & $\begin{array}{l}\text { Hajdú Pál } \\
\text { r. ezredes }\end{array}$ & 1967. 03. 15. & 1971. 05. 31. & 1922-1994 \\
\hline \multirow{3}{*}{$\begin{array}{l}\frac{\dot{y}}{z} \\
\frac{\sum}{\Sigma}\end{array}$} & vezető & $\begin{array}{c}\text { Dr. Selmeczi György } \\
\text { r. ezredes }\end{array}$ & 1971. 07. 01. & 1976. 08. 31. & 1921-1979 \\
\hline & $\begin{array}{c}\text { megbízott } \\
\text { vezető }\end{array}$ & $\begin{array}{c}\text { Dr. Fekete Károly } \\
\text { r. alezredes }\end{array}$ & 1976. 09. 01. & 1977. 02. 28. & 1926-2010 \\
\hline & $\begin{array}{c}\text { megbízott } \\
\text { vezető }\end{array}$ & $\begin{array}{c}\text { Csajkovits József } \\
\text { r. alezredes }\end{array}$ & 1977. 03. 01. & 1977. 05. 31. & 1933- \\
\hline \multirow{3}{*}{$\begin{array}{l}\stackrel{U}{\tilde{U}} \\
\text { 픈 } \\
\underline{\Perp} \\
\sum_{\infty}\end{array}$} & csoportfőnök & $\begin{array}{c}\text { dr. Kamara János } \\
\text { r. ezredes }\end{array}$ & 1971. 06. 18 & 1974. 06. 21. & 1927-2000 \\
\hline & csoportfőnök & $\begin{array}{l}\text { Pados Gábor } \\
\text { r. alezredes }\end{array}$ & 1975. 01. 01. & 1976. 12. 31. & 1929-2007 \\
\hline & csoportfőnök & $\begin{array}{c}\text { Baranyai György } \\
\text { r. vezérőrnagy }\end{array}$ & 1977. 01. 01. & 1977. 05. 31. & 1927-1998 \\
\hline
\end{tabular}


CSIZNER Zoltán: A bünügyi adatfeldolgozás hazai fejlődése...

\begin{tabular}{|c|c|c|c|c|c|}
\hline \multicolumn{2}{|c|}{ Szervezet, beosztás } & \multirow{2}{*}{$\begin{array}{c}\text { Név } \\
\text { Baranyai György } \\
\text { r. vezérőrnagy }\end{array}$} & \multicolumn{2}{|c|}{ Hivatalban } & \multirow{2}{*}{$\begin{array}{c}\text { Élete } \\
1927-1998\end{array}$} \\
\hline \multirow{6}{*}{ 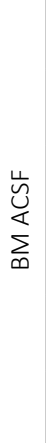 } & csoportfőnök & & 1977. 06. 01. & 1983. 12. 31. & \\
\hline & BNYO vezető & $\begin{array}{c}\text { Dr. Fekete Károly } \\
\text { r. ezredes }\end{array}$ & 1977. 06. 01. & 1981. 03. 31. & 1926-2010 \\
\hline & $\begin{array}{l}\text { Értékelő-Táj. } \\
\text { Osztály vezető }\end{array}$ & $\begin{array}{c}\text { Dr. Balogh Sándor r. } \\
\text { ezredes }\end{array}$ & 1977. 06. 01. & $?$ & 1927-2015 \\
\hline & $\begin{array}{l}\text { Gépi Adatfeld. } \\
\text { Osztály vezető }\end{array}$ & $\begin{array}{c}\text { Csajkovits József } \\
\text { r. alezredes }\end{array}$ & 1977. 06. 01. & 1987. 12. 31. & $1933-$ \\
\hline & $\begin{array}{l}\text { Lakcím és Közl. } \\
\text { Osztály vezető }\end{array}$ & $\begin{array}{l}\text { Detrői Ernő } \\
\text { r. alezredes }\end{array}$ & 1977. 06. 01. & $?$ & 1925-2017 \\
\hline & $\begin{array}{c}\text { ÁB Op. Ny. } \\
\text { Osztály vezető }\end{array}$ & $\begin{array}{l}\text { Viczián István } \\
\text { r. alezredes }\end{array}$ & 1977. 06. 01. & 1980. 07. 31. & $1925-2012$ \\
\hline
\end{tabular}

* A beosztást az 1973. III. tv. alapján, 1973 novemberében hozták létre.

** A BNYSO a korábbi BNYO és SÉO egymásba olvadásával jött létre, a pontos időpont nem ismert. A BM II. Főcsoportfőnökség (ORFK) 1965. január 1-jétől érvényes új ügyrendjében (002/1965. számú belügyminiszter-helyettesi utasítás) már nem szerepel az önálló II/1. osztály, és a statisztikai adatok feldolgozása már a II/1. csoportfőnökség feladata.

Forrás: a szerző összeállítása az Állambiztonsági Parancsgyűjtemény, az Állambiztonsági Szolgálatok Történeti Levéltára Archontológia, a Nemzeti Emlékezet Bizottsága és a Wikipedia adatainak felhasználásával

\section{2. sz. melléklet}

Minták a Tájékoztató és Koordinációs Központnál használt adatlapokból

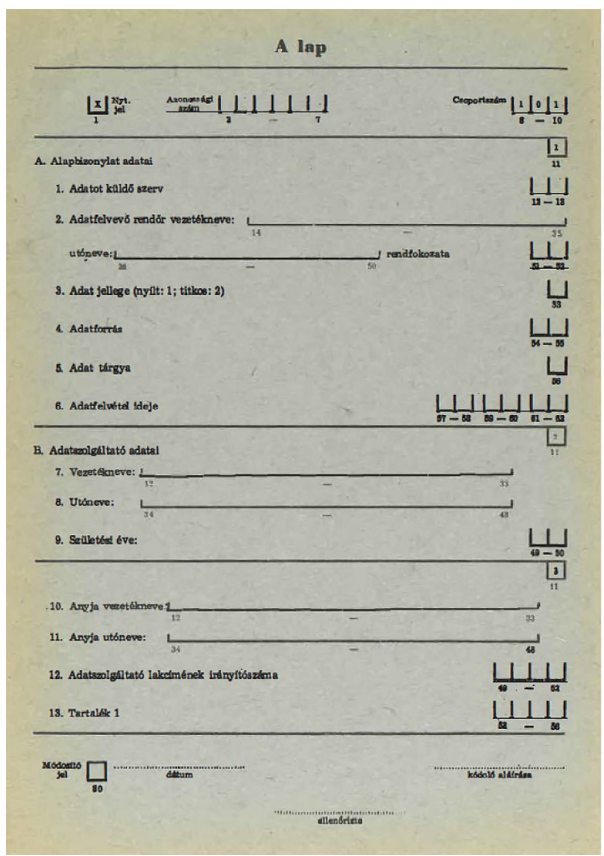

„A" adatlap az alapbizonylatról

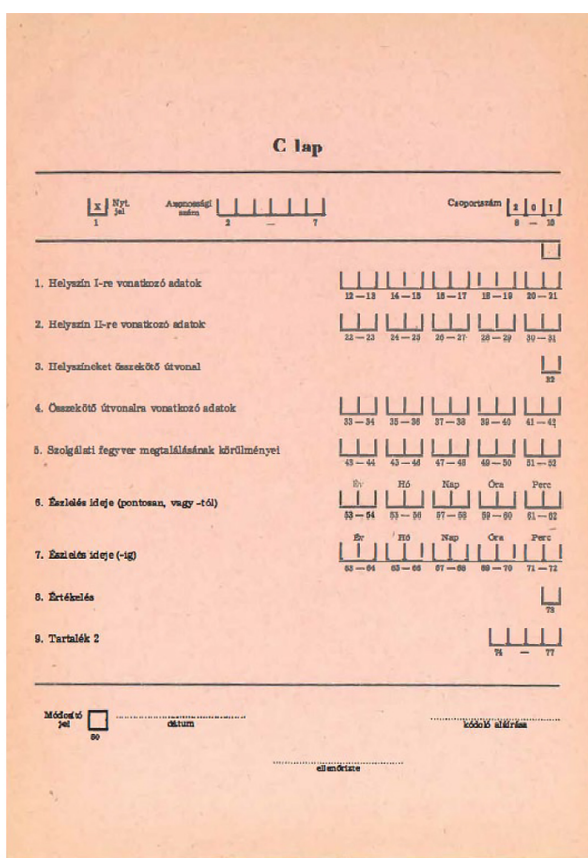

„C" adatlap az alapbizonylatról 


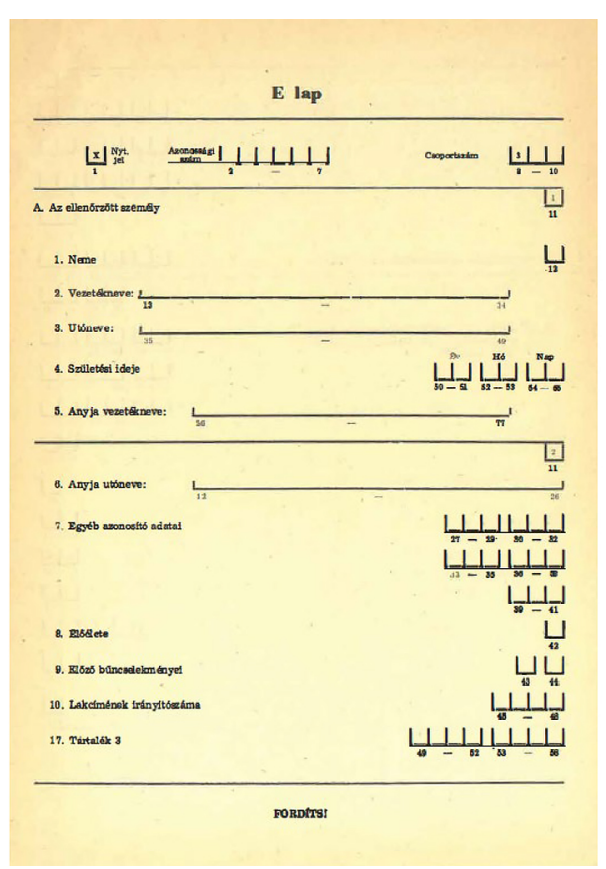

„E" adatlap az alapbizonylatról

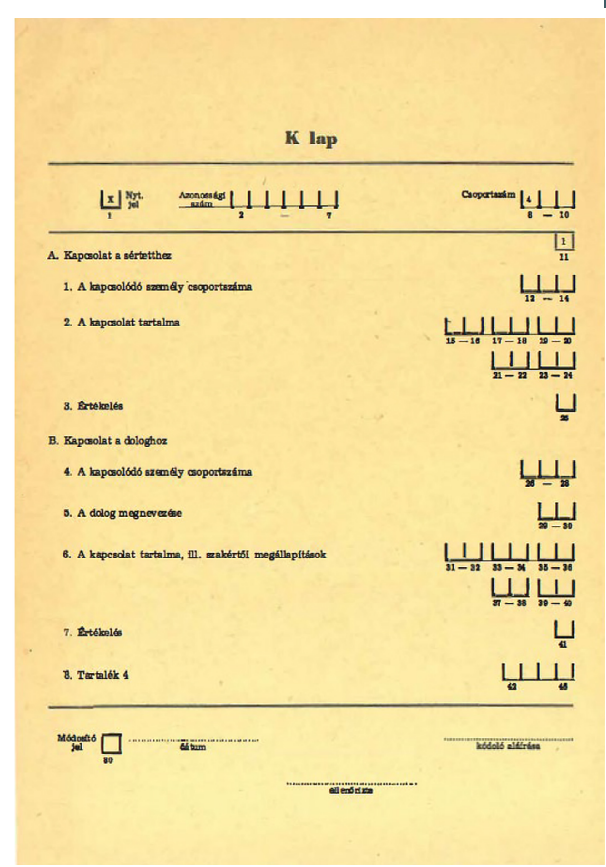

„K” adatlap az alapbizonylatról

Forrás: Kacziba Antal 1979. december 19-én kelt „Tájékoztató és Koordinációs Központ szervezésének és az információk számítógépes feldolgozásának tapasztalatairól” szóló jelentésének melléklete

\section{Felhasznált irodalom}

0014/1965. (IX. 17.) BM utasítás a BM Bünügyi Nyilvántartó Osztály nyilvántartási anyagának selejtezéséről (ÁBTL- 4.2.-10- 22/14/1965.)

002/1965. számú belügyminiszter-helyettesi utasítás

0021/1965.(VI. 1.) és a 0023/1965. (VI.1.) belügyminiszteri parancsok (ÁBTL-4.2.-10-

21/21/1965. és ÁBTL-4.2.-10-21/23/1965)

018/1974. (XI. 18.) belügyminiszteri parancs (ÁBTL-4.2-10-21/18/1974.)

02/1974. (IV. 8.) BM Információfeldolgozó és Felügyeleti Csoportfőnöki Utasítás (ÁBTL- 4.2-65-6-2/1974.)

08/1971. (VI. 18.) belügyminiszteri parancs, 1971. július 1-jén lépett hatályba. (ÁBTL4.2-10-21/8/1971.)

1/1957. (III. 19.) BM számú rendelet a rendőrhatósági felügyeletről

34/1977. (XII. 1.) BM parancs a számítástechnika belügyi alkalmazásának, a számítógépes információrendszerek fejlesztésének egységes szabályozásáról. (ÁBTL4.2-10-22/34/1977.) 
34/1977. számú belügyminiszteri parancs A számítástechnika belügyi alkalmazásának, a számítógépes információrendszerek fejlesztésének egységes szabályozásáról; „A számítástechnika belügyi alkalmazásának fejlesztési irányelvei” címü melléklete (ÁBTL- 4.2-10-22/34/1977/11.)

50-130/1978. BM ORFK I-1. osztály Intézkedési Terve (ÁBTL- 4.2-50-130/1978)

5372-1/1950. (VIII. 11.) BM rendelet „Az országos bűnügyi nyilvántartással kapcsolatos tennivalók ellátása és a körözések közzététele" tárgyában

9/1977. (V. 30.) belügyminiszteri parancs (ÁBTL- 4.2-10- 22/9/1977.)

A 0020/1967. (VII. 29.) belügyminiszteri parancs 1969. 11. 30-án kelt végrehajtási utasításának 3. pontja (ÁBTL-4.2.-10-21/20/1967/14.)

A 0020/1967. (VII. 29.) belügyminiszteri parancs, és annak végrehajtási utasításai (ÁBTL-4.2.-10-21/20/1967.)

A 01/1967. számú belügyminiszter-helyettesi parancs mellékleteként kiadott, „A bűnügyi nyilvántartás szabályzata, I-II." (ÁBTL-4.2.-10-1190/1967. és ÁBTL-4.2.-10-11901/1967.)

Nemzeti Emlékezet Bizottsága: Az 1945-1988. között magyar bíróságok ítélete alapján kivégzettek. Online: https://neb.hu/asset/php0CAlKM.pdf

Az 1954. január 08-án kiadott, 02. számú belügyminiszter-helyettesi parancs, és annak 239/1953. számú melléklete

Az ORFK vezetőjének 1958. május 5-én kelt 5. számú utasítása és annak melléklete (ÁBTL-4.2-50-6/5/1958)

BM Titkárság 10-1513/1962. számú, 1962. 08. 29-én kelt körlevele (ÁBTL-4.2.-101513/1962.)

Boda József - Regényi Kund: A hírszerző és biztonsági szolgálatok fejlődése a második világháború végéig. In Boda József - Regényi Kund (szerk.): A hírszerzés története az ókortól napjainkig. Budapest, Dialóg Campus, 2019. 111-143. Online: https:// tinyurl.hu/k9lH/

Cseh Gergő Bendegúz - Tóth Eszter: A magyar állambiztonsági szervek központi nyilvántartási rendszere és annak számítógépesítése (1962-1990). In A Nemzeti Emlékezet Bizottsága és az Állambiztonsági Szolgálatok Történeti Levéltára közös munkacsoportjának jelentése az 1990 előtti állambiztonsági szervek mágnesszalagokon megörzött adatállományának vizsgálatáról. Nemzeti Emlékezet Bizottsága, 2017.9-49. Online: www.abtl.hu/sites/default/files/pdf/Magnesszalag_jelentes.pdf

Déri Pál: Korszerü nyomozás - integrált bűnüldözés. Budapest, BM Tanulmányi és Propaganda Csoportfönökség, 1976.

Déri Pál - Budai Attila: Korszerü bünüldözés. Budapest, Országos Rendőr-főkapitányság, 1991.

Déri Pál: Az állam és a társadalom kötelezettségei a bűnözés elleni harcban. In Bócz Endre (főszerk.): Kriminalisztika. II. Budapest, BM, 2004. 925-968.

Dolgozók Lapja, 32. (1979), 213. 8. Online: https://library.hungaricana.hu/hu/view/ KomaromEsztergom24ora_1979_09/?pg=80\&layout=s

Dunántúli Napló, 36. (1979), 280. Online: https://library.hungaricana.hu/hu/view/ DunantuliNaplo_1979_10/?pg=99\&layout=s

Finkey Ferencz: A magyar büntetőjog tankönyve. Budapest, Grill Károly, 1914. 
Finszter Géza: A kriminalisztika ígérete. Magyar Tudomány, 181. (2020), 5. 591603. Online: https://doi.org/10.1556/2065.181.2020.5.3

Gödöny József: Nemzetközi erőfeszítések a búnözés visszaszorítására. Jogtudományi Közlöny, 30. (1975), 9. 497-504. Online: http://real-j.mtak.hu/2229/1/JogtudomanyiKozlony_1975.pdf

Heti Híradó 21. (19777. 04. 09.) 15. 3. Online: http://epa.oszk.hu/02800/02851/00954/ pdf/EPA02851_heti_hirado_19770409-21-15.pdf

Ismeretlen szerző: „Kétszázezer ujjlenyomat van már a rendőrség birtokában” Demokrácia (1946) 23. 7. Online: https://adt.arcanum.com/hu/view/Demokracia_1946_1/?pg=188\&layout=s

Kacziba Antal 1979. december 19-én kelt jelentése a Tájékoztató és Koordinációs Központ szervezésének és az információk számítógépes feldolgozásának tapasztalatairól

Kacziba Antal 1979. december 19-én kelt „Tájékoztató és Koordinációs Központ szervezésének és az információk számítógépes feldolgozásának tapasztalatairól" szóló jelentésének melléklete

Kacziba Antal által készített és Katona Géza által jóváhagyott, 1979. 08. 07-én kelt javaslat a nyomozás során keletkezett adatok számítógépes rendszerezésére

Konczer István 1979. december 14-ei összefoglaló jelentése a nyomozásról

Kovács Tamás: Megfigyelés, internálás, deportálás az internálás és a toloncolás kérdésköre a két világháború között, különös tekintettel a Il. világháború korára. Doktori értekezés. Pécs, PTE BTK Interdiszciplináris Doktori Iskola, 2013.

Központi Statisztikai Hivatal adatai. Online: www.ksh.hu/docs/hun/xstadat/xstadat_hosszu/h_zjj001.html

Magyar Hírlap, 18. (1985), 113. Online: https://adt.arcanum.com/hu/view/MagyarHirlap_1985_05/?pg=136\&layout=s

Müller Rolf: Az operatív technikai osztály, 1956-1962. Betekintő, (2011), 3. 6. Online: https://betekinto.hu/sites/default/files/betekinto-szamok/2011_3_muller.pdf

Nemzeti Emlékezet Bizottsága: A Belügyminisztérium szervezete, mellékletek: Államtitkári szervek 1974. Online: https://neb.hu/asset/phpadHQ5g.pdf

Perényi Roland: A bün nyomában. A budapesti bünözés társadalomtörténete 1896-1914. Budapest, L'Harmattan, 2012.

Rudas György: A bünügyi nyilvántartás fejlődése. Rendőrségi Szemle, 7. (1959), 1. 22-31.

Szűcs Gábor: Jogerős ítéletet hirdettek a rendőrgyilkosok ügyében. Esti Hírlap, 25. (1980), 213. 8.

Tóth Ferenc - Kétyi Károly: Szállodai tűzesetek nyomozása. In Korinek László - Finszter Géza (szerk.): 60 év, hatvan büncselekmény II. Budapest, Belügyi Szemle, 2012. 20-23.

Vedres Géza: Rendőrgyilkosság az 5. számú őrhelyen. In Korinek László - Finszter Géza (szerk.): 60 év, hatvan büncselekmény II. Budapest, Belügyi Szemle, 2012. 13. 
CSIZNER ZoltÁn: A bünügyi adatfeldolgozás hazai fejlődése...

\section{Jogi forrás}

13/2001. (X. 2.) ORFK utasítás a Magyar Köztársaság Rendőrsége Bűnelemzési Szabályzatának kiadásáról 